INTER NATIONAL MONETARY FUND

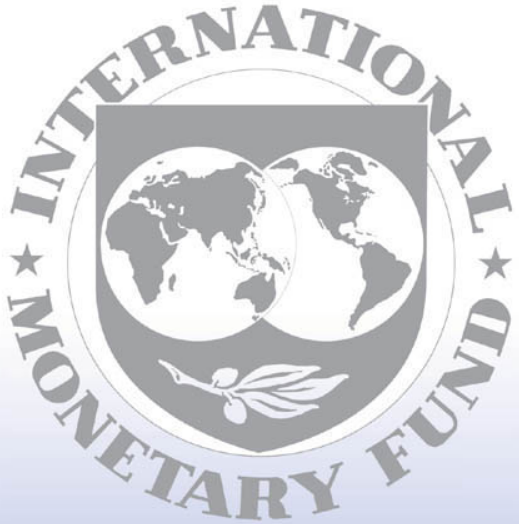

Staff

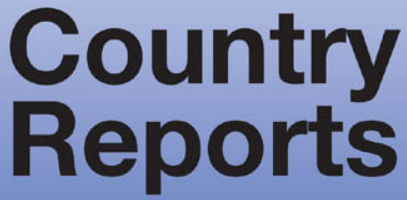




\section{People's Republic of China-Hong Kong Special Administrative Region: 2006 Article IV Consultation-Staff Report; Staff Statement; Public Information Notice on the Executive Board Discussion}

Under Article IV of the IMF's Articles of Agreement, the IMF holds bilateral discussions with members, usually every year. In the context of the 2006 Article IV consultation with the People's Republic of China-Hong Kong Special Administrative Region, the following documents have been released and are included in this package:

- the staff report for the 2006 Article IV consultation, prepared by a staff team of the IMF, following discussions that ended on October 24, 2006, with the officials of the People's Republic of China-Hong Kong Special Administrative Region on economic developments and policies. Based on information available at the time of these discussions, the staff report was completed on November 27, 2006. The views expressed in the staff report are those of the staff team and do not necessarily reflect the views of the Executive Board of the IMF.

- $\quad$ a staff statement of December 15, 2006 updating information on recent developments.

- $\quad$ a Public Information Notice (PIN) summarizing the views of the Executive Board as expressed during its December 15, 2006 discussion of the staff report that concluded the Article IV consultation.

The document listed below have been or will be separately released.

\section{Selected Issues Paper}

The policy of publication of staff reports and other documents allows for the deletion of market-sensitive information.

To assist the IMF in evaluating the publication policy, reader comments are invited and may be sent by e-mail to publicationpolicy@imf.org.

Copies of this report are available to the public from

International Monetary Fund • Publication Services

$70019^{\text {th }}$ Street, N.W. • Washington, D.C. 20431

Telephone: (202) 623-7430 • Telefax: (202) 623-7201

E-mail: publications@imf.org • Internet: http://www.imf.org

Price: $\$ 18.00$ a copy

\section{International Monetary Fund \\ Washington, D.C.}


This page intentionally left blank

(C) International Monetary Fund. Not for Redistribution 
INTERNATIONAL MONETARY FUND

\title{
PEOPLE'S REPUBLIC OF CHINA-HONG KONG SPECIAL ADMINISTRATIVE REGION
}

\section{Staff Report for the 2006 Article IV Consultation Discussions}

\begin{abstract}
Prepared by the Staff Representatives for the 2006 Consultation Discussions with Hong Kong Special Administrative Region
\end{abstract}

Approved by Wanda Tseng and Adrienne Cheasty

November 27, 2006

Discussions: Hong Kong SAR, October 16-24 2006. The team met with Financial Secretary Henry Tang, Hong Kong Monetary Authority Chief Executive Joseph Yam, Financial Services and the Treasury Secretary Frederick Ma, and other senior government officials and private sector representatives. The mission also met with representatives from political parties and NGOs.

Team: Messrs. Aziz (Head), Aitken, Porter, Syed (all APD), and Mr. Craig (MCM). Mr. Gruenwald (Resident Representative) assisted the mission. Mr. Ge, Executive Director, and Ms. Lo (OED) joined the mission.

Economic Setting: Hong Kong SAR's current economic expansion has now been sustained for nearly 12 quarters, with domestic demand playing an increasingly dominant role. Inflation remains subdued and unemployment has eased to a more than five year low.

Political Setting: The current term of Chief Executive Donald Tsang ends in mid-2007; he is expected to seek re-election. The next legislative elections are scheduled for 2008.

Mission Focus: Given the generally favorable economic situation, this year's consultation was streamlined, focusing on: the fiscal policy challenges of aging and volatile revenue; enhancing competitiveness and managing the expanding financial links with the Mainland.

Past Fund Advice: The Fund has generally supported the authorities' policies and structural reforms, including their commitment to the Linked Exchange Rate System (LERS).

Exchange Arrangement: Currency board - the LERS - with a trading band of Hong Kong dollar 7.75-7.85 per U.S. dollar. Obligations under Article VIII have been accepted for Hong Kong SAR, and the exchange system is free of restrictions for current international transactions.

Principal Author: Nathan Porter. 
Contents

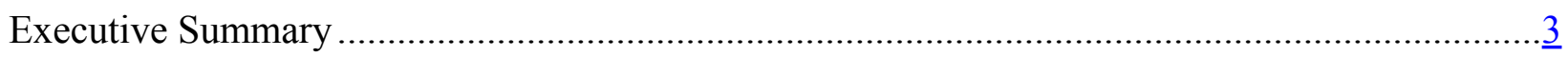

I. Economic Setting: From Recovery to Sustained Growth......................................................

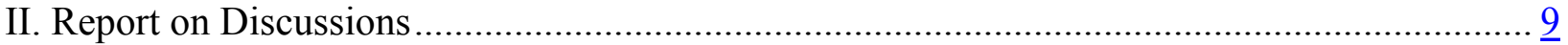

A. Fiscal Policy: Looking Beyond the Good Times ....................................................... $\underline{9}$

B. Exchange Rate Regime: A More Resilient System................................................ 12

C. Competitiveness: Building on Traditional Strengths and Financial Development....... 15

III. Staff Appraisal

Figures

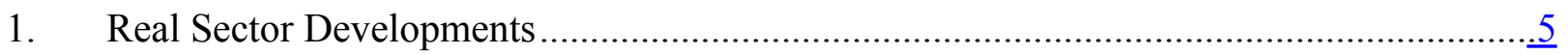

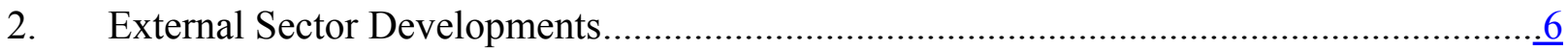

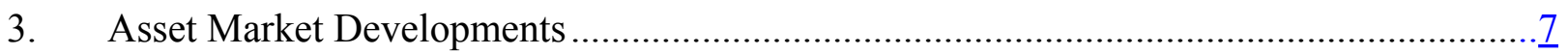

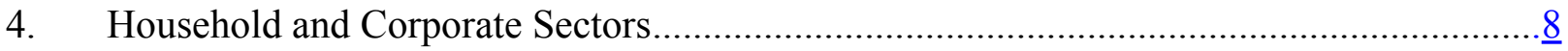

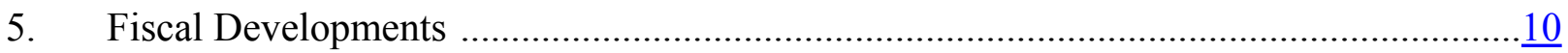

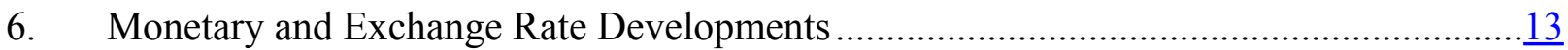

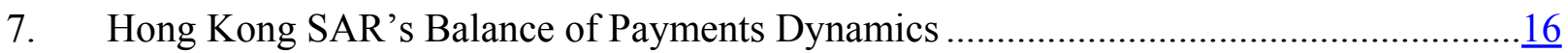

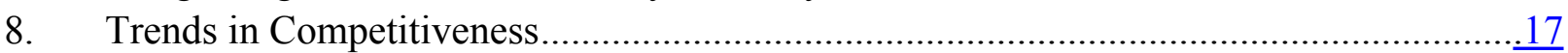

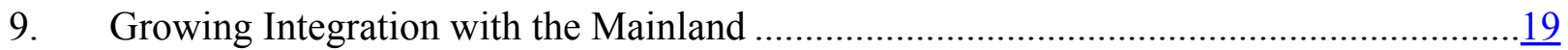

Tables

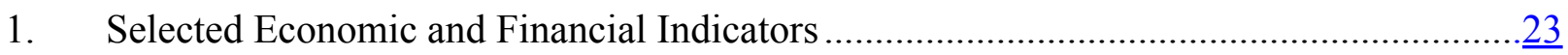

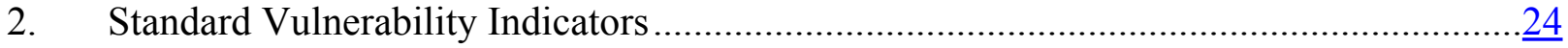

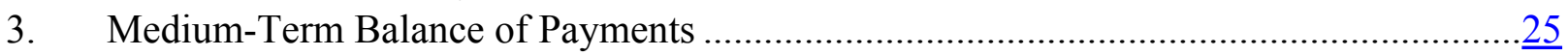

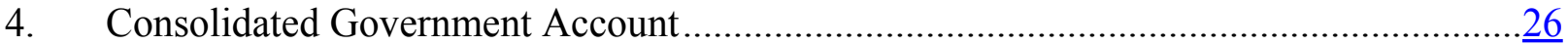




\section{Executive Summary}

\section{Economic Setting}

Hong Kong SAR has recovered strongly from a series of shocks in recent years and, as expected, the pace of growth is now moderating. Unemployment is at a more than five year low and inflation modest. Skillful macroeconomic management, financial market development, and the flexibility of Hong Kong SAR's markets were key to this recovery. Looking ahead, staff expects growth to continue, but at a more moderate pace, with the main near-term risk to this outlook a sharp slowdown in global demand. Over the medium term, much will depend on how further financial integration with the Mainland is managed and leveraged.

\section{Policy Discussions}

With the near-term economic situation bright, the consultation was streamlined, focusing on medium-term challenges related to fiscal prospects and ways to enhance competitiveness, including by advancing the ongoing financial integration with the Mainland.

- $\quad$ Fiscal Challenges: With the budget returning to surplus, the main challenges are associated with fiscal pressures arising in the medium term, and managing continued revenue volatility. The authorities are planning to reform healthcare delivery and financing systems to address age-related pressures. To stabilize revenue, the government has opened a public consultation with the proposed introduction of a goods and services tax as its focal point. However, the proposal faces strong public opposition and the authorities plan to use the results of this consultation to develop more concrete proposals at a later date.

- $\quad$ Exchange Rate Policy: The staff continues to support the authorities' commitment to the Linked Exchange Rate System, which was strengthened by the May 2005 refinements.

- Competitiveness and Expanding Mainland Financial Links: Economic prospects will crucially depend on how well financial integration with the Mainland is managed. Efforts at coordinating with the Mainland authorities on ways of using Hong Kong SAR's advanced financial infrastructure to improve the Mainland's financial intermediation are beginning to bear fruit. At the same time, the authorities are aware of the need to protect their reputation for strong market infrastructure and supervision. In this regard, they are advanced in their preparation for Basel II adoption, remain proactive in monitoring for signs of equity market stress, and have plans to broaden anti-money laundering/combating the financing of terrorism (AML/CFT) enforcement. 


\section{ECONOMIC SETting: From ReCOVERY TO SUSTAINED Growth}

\section{Hong Kong SAR's current economic expansion, which began in mid-2003 after} the end of the SARS outbreak, has now been sustained for nearly 12 quarters. Initially the turnaround was driven by external demand, but in recent quarters, domestic demand has played the dominant role. The expansion has ended a nearly six-year long deflation, reduced unemployment to its lowest level in more than five years, and helped revive asset prices (Figures 1-4).

\section{Underlying the recovery was the} flexibility of Hong Kong SAR's labor and product markets, supportive fiscal policy, and continued structural reforms, especially as the Linked Exchange Rate System (LERS) precluded active monetary stimulus. Also key was the strong external environment, particularly the growing and multi-faceted economic integration with China, which has already seen Hong Kong SAR successfully transform itself into the services hub for the Mainland (especially the Pearl River Delta

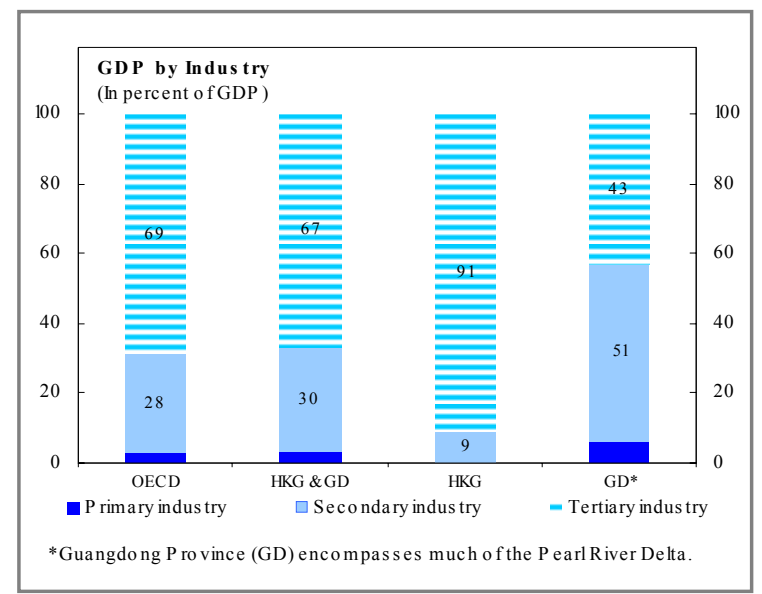
region). Indeed, the initial turnaround was triggered by the confidence building effects of the 2003 Closer Economic Partnership Arrangement (CEPA), a free-trade arrangement with the Mainland.

3. The pace of growth has, expectedly, begun to moderate. The staff expects GDP growth to slow to $5 \frac{1}{2}-6$ percent this year from 7.3 percent last year. This reflects a slowing of external demand largely due to the softening in the U.S. economy, partly offset by strong domestic demand, backed by robust household and corporate balance sheets. Inflation is expected to firm modestly with the tightening labor market and as rents adjust to previous increases in property prices. With the slowdown in external demand, the current account surplus should narrow to around $91 / 4$ percent of GDP this year from around $11 \frac{1}{2}$ percent of GDP in 2005. The main near-term risks are an even sharper slowdown in global demand (particularly in the United States), a rise in protectionist pressures against the Mainland, or a disorderly adjustment in the global financial system. ${ }^{1}$ The risk of an Avian flu outbreak appears less immediate and preparedness for such an eventuality is well advanced. If financial integration with the Mainland is deepened and managed well, and competitive pressures from other regional financial centers withstood, growth could average around 5 percent over the medium term with low inflation and some further narrowing of the current account surplus.

\footnotetext{
${ }^{1}$ Staff estimates suggest that a 1 percentage point reduction in U.S. growth (through trade channels) could reduce Hong Kong SAR's growth by $1 / 2-1$ percentage point, depending on its spillover impact on China's economy. The impact through financial channels is difficult to pin down with confidence.
} 
Figure 1. Real Sector Developments

After rising rapidly for 3 years, growth is now moderating, while consumer confidence remains buoyant...

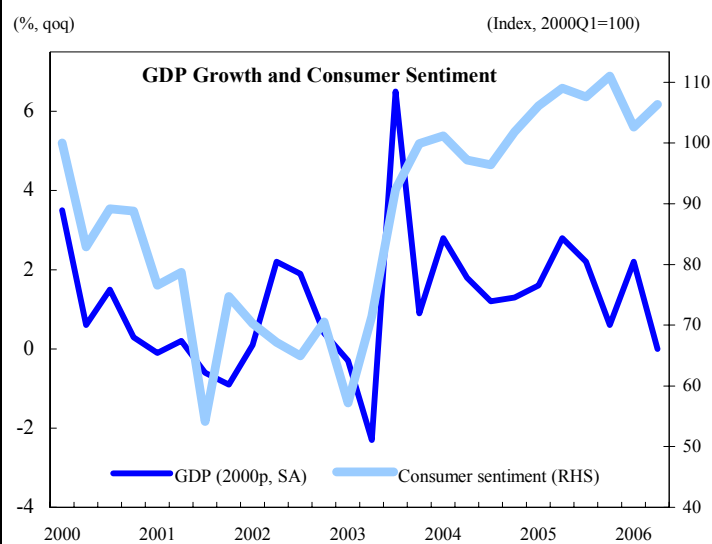

Domestic demand has emerged as a key driver of growth in recent quarters.

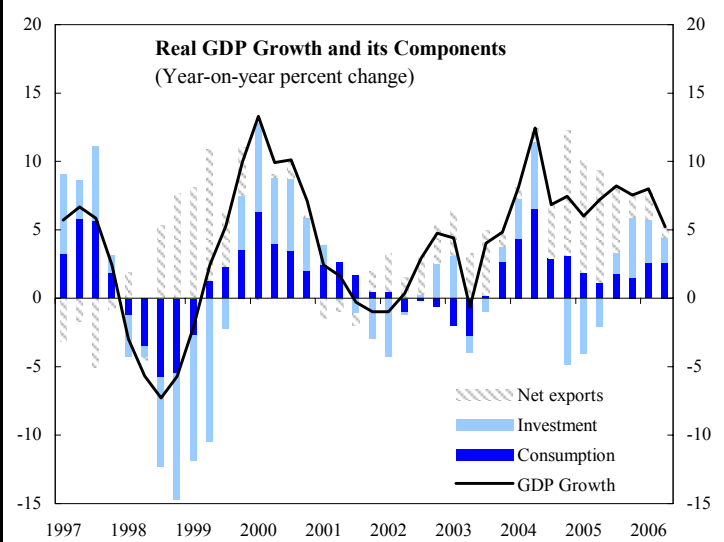

Unemployment has fallen to its lowest level since $2001 \ldots$

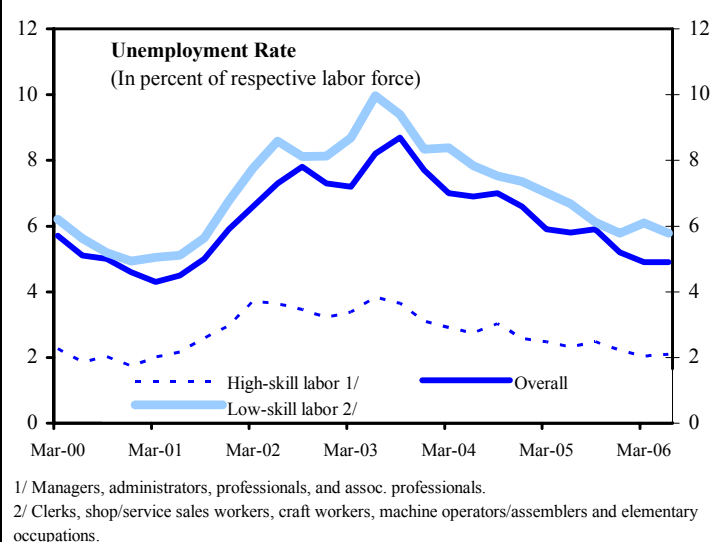

...with business sentiment also sanguine.

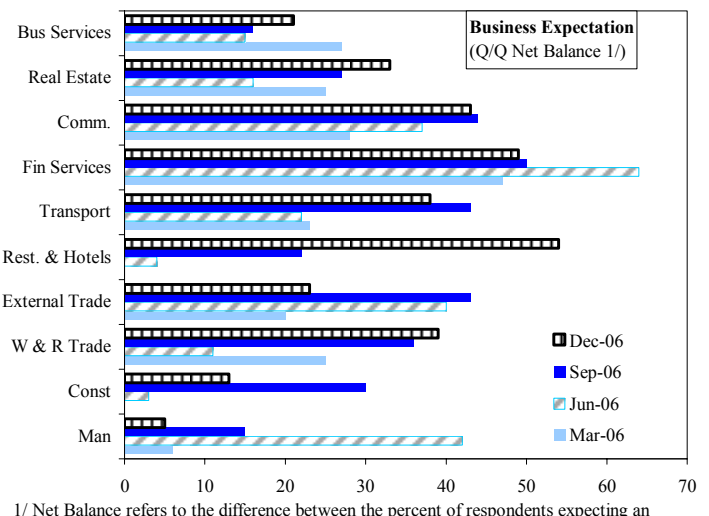

1/ Net Balance refers to the difference between the percent of respondents expecting an improvement and those expecting a decline.

Inflation is low, despite some pick up in rents.

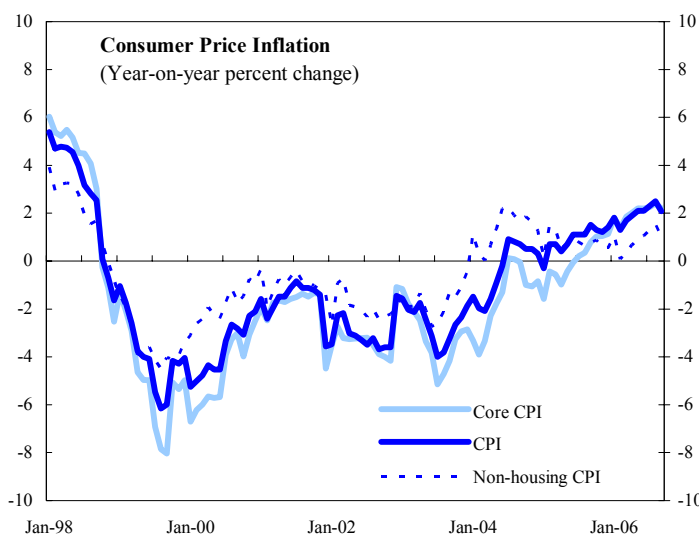

...but remains high in some sectors and among the lowskilled.

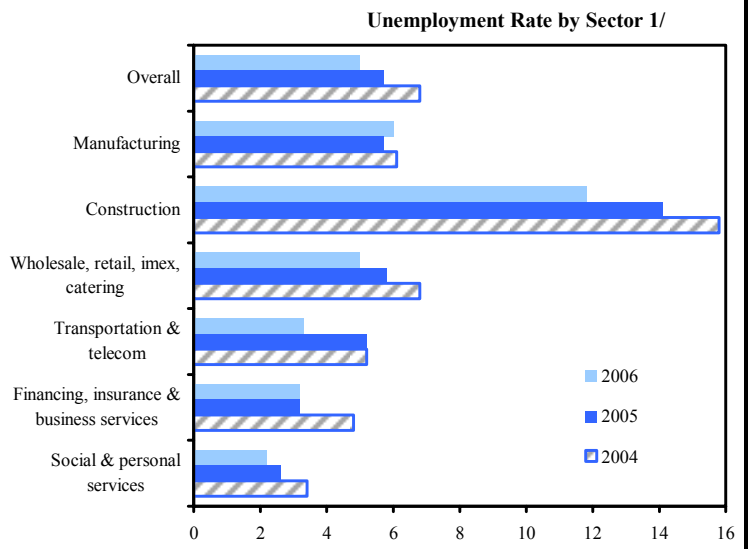

1/ Seasonally unadjusted estimates for mid-year (June).

Sources: CEIC, Hong Kong SAR authorities and staff estimates. 


\section{Figure 2. External Sector Developments}

Total exports fell sharply in the second quarter of $2006 .$. ...but re-exports recovered somewhat in the third quarter.

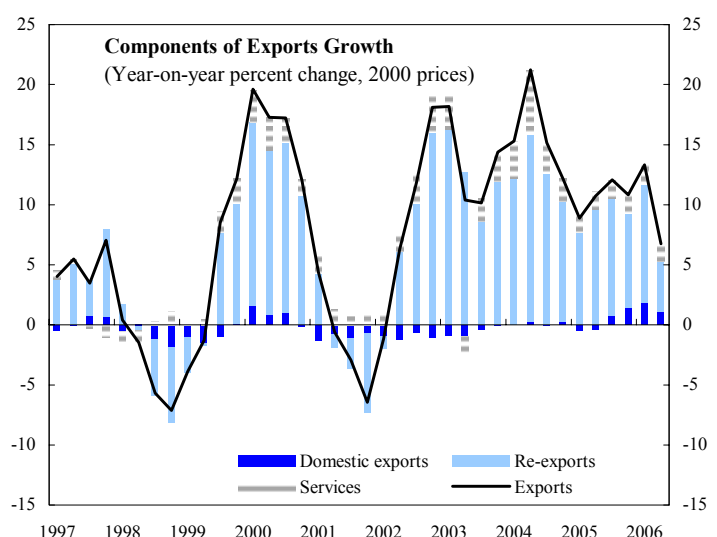

Imports for domestic use have been growing.

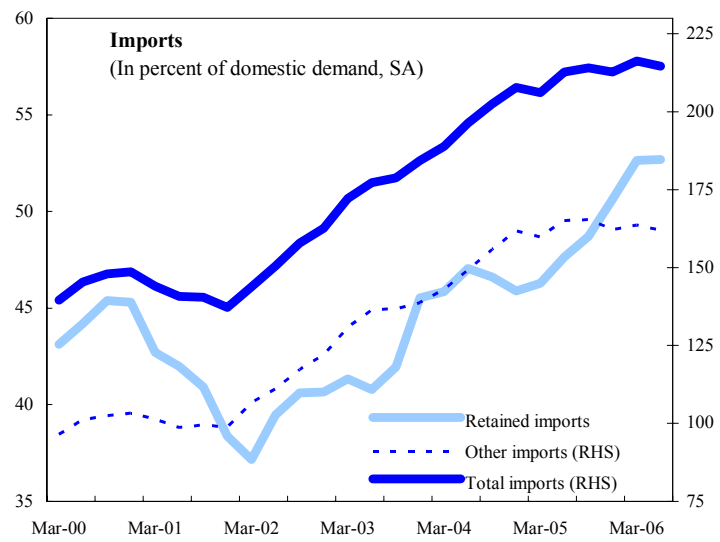

Official reserves remain broadly stable...

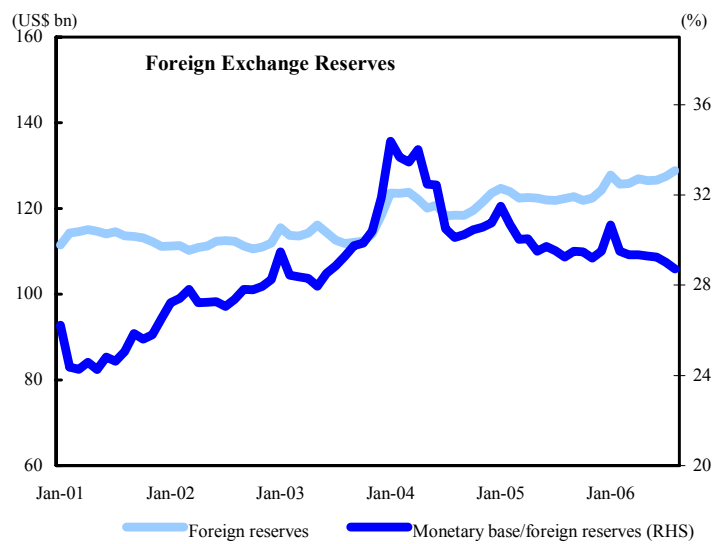

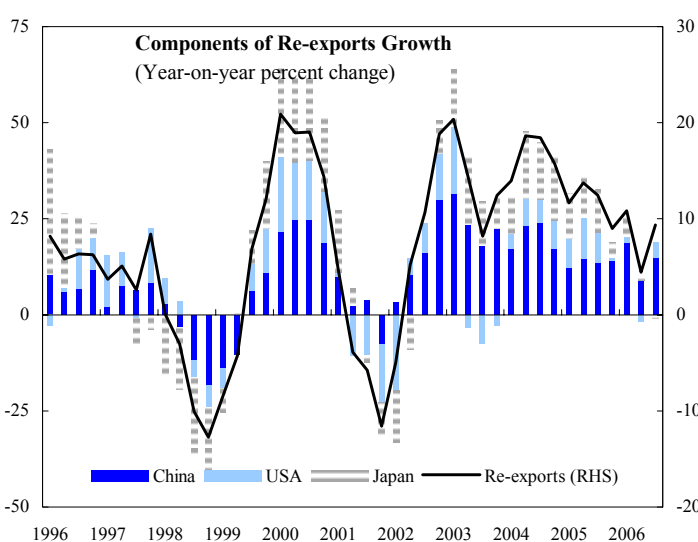

The current account surplus has narrowed, as have net capital outflows.

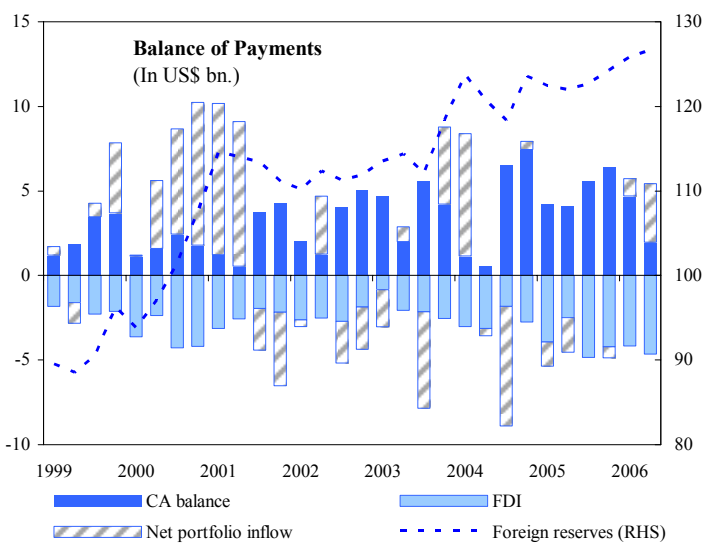

...while overall net foreign assets have continued to rise.

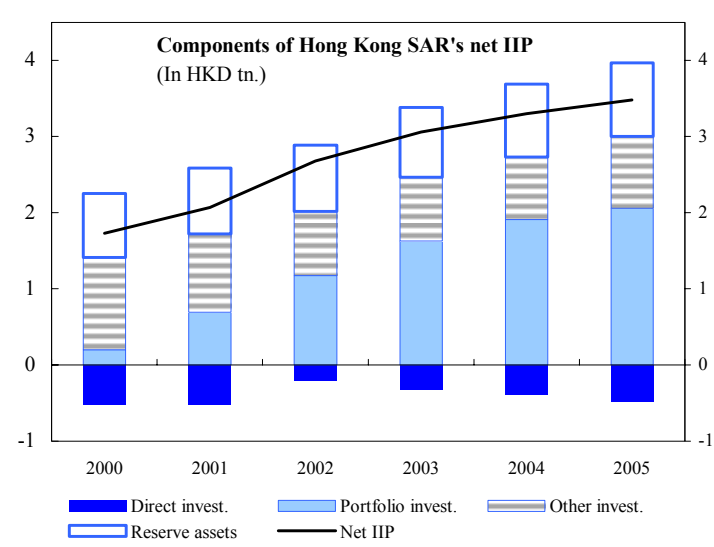

Sources: CEIC, Hong Kong SAR authorities and staff estimates. 
Figure 3. Asset Market Developments

Equity prices have revived,...

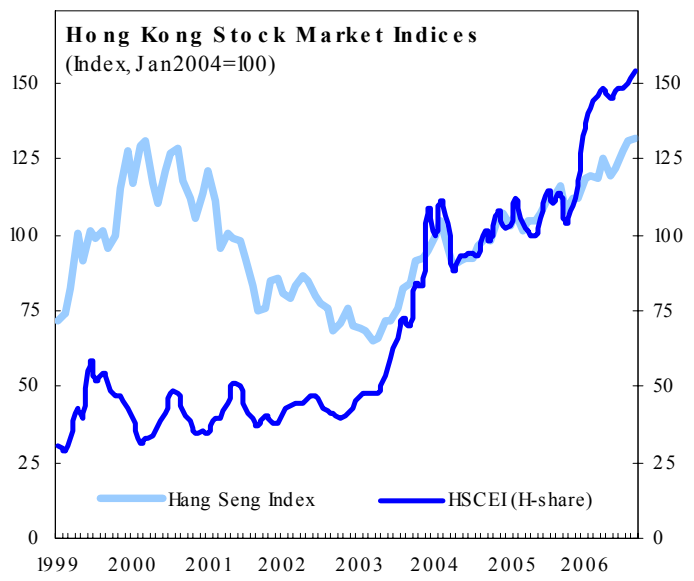

Hong Kong's Stock Exchange surpassed New York's in IPO fundraising this year.

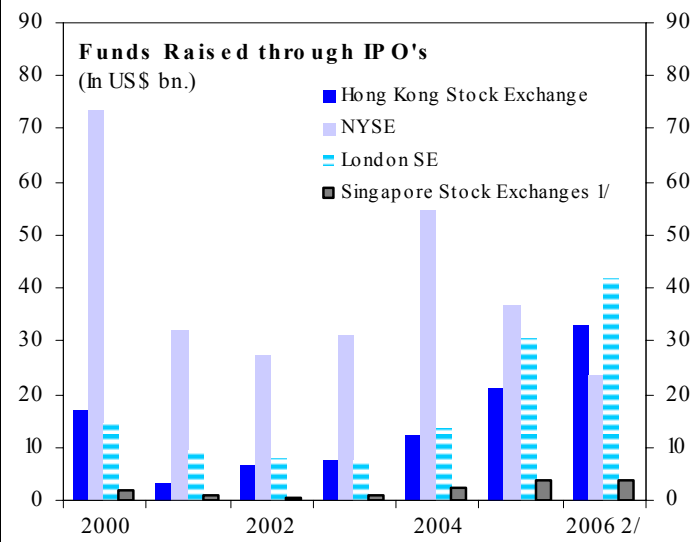

1/ Capital raised on SGX Main Board \& SGX Sesdaq.

2/ Year-to-date as of October 2006.

The equity-derivatives market continues to expand ...

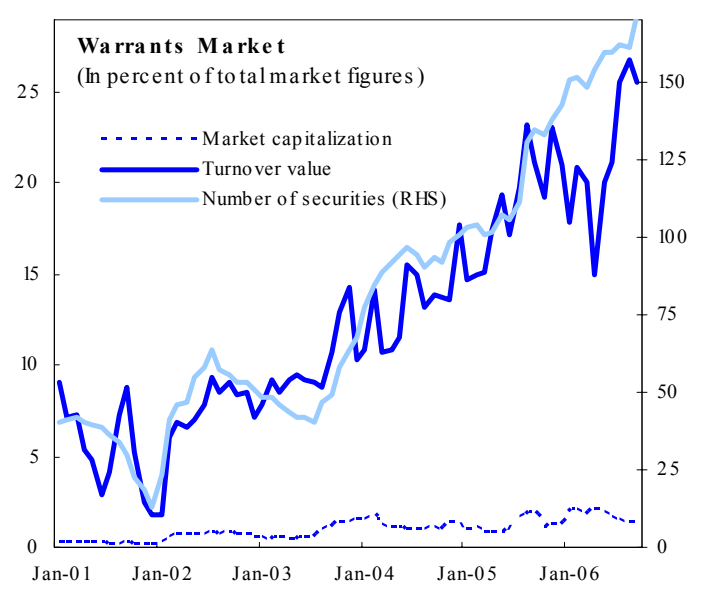

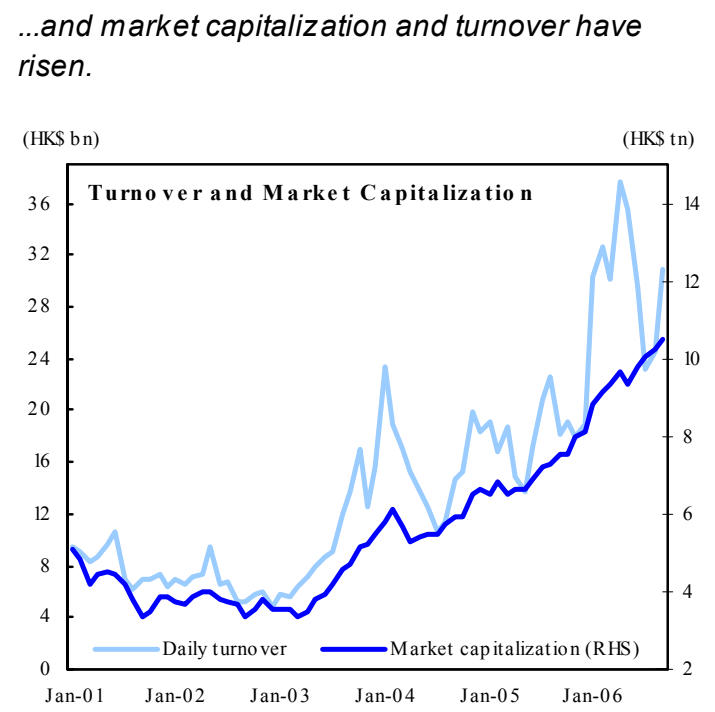

After rising strongly in 2003-05, property prices have stabilized.

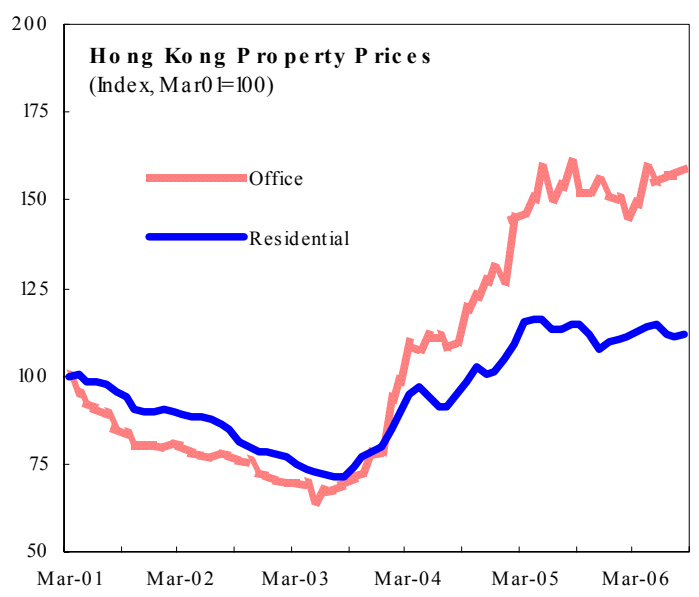

...while the debt market has also grown.

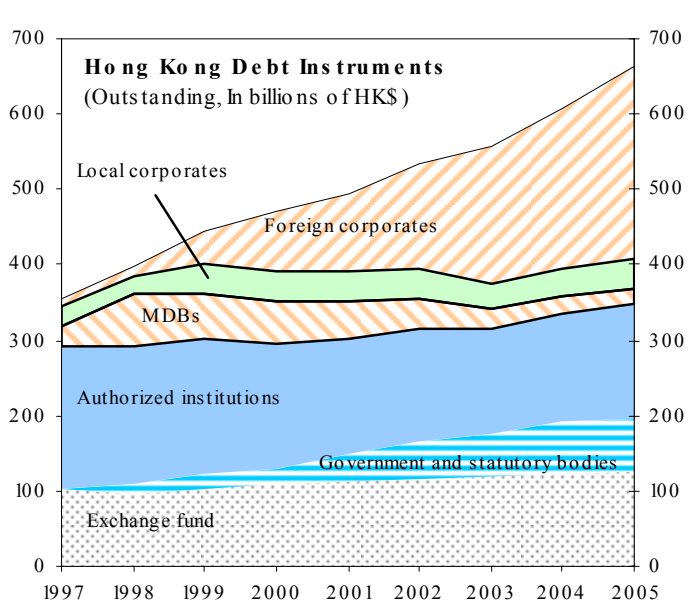

Sources: CEIC, World Federation of Exchanges, Hong Kong SAR authorities and staff estimates. 


\section{Figure 4. Household and Corporate Sectors}

Household and corporates balance sheets have improved significantly as delinquency and bankruptcy rates declined...

('000s)

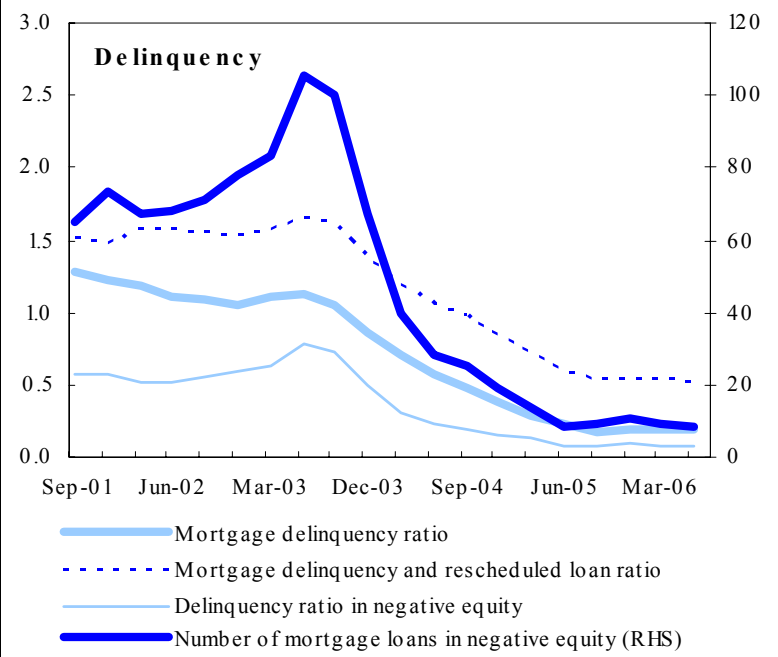

...and corporate earnings and profits grew strongly...
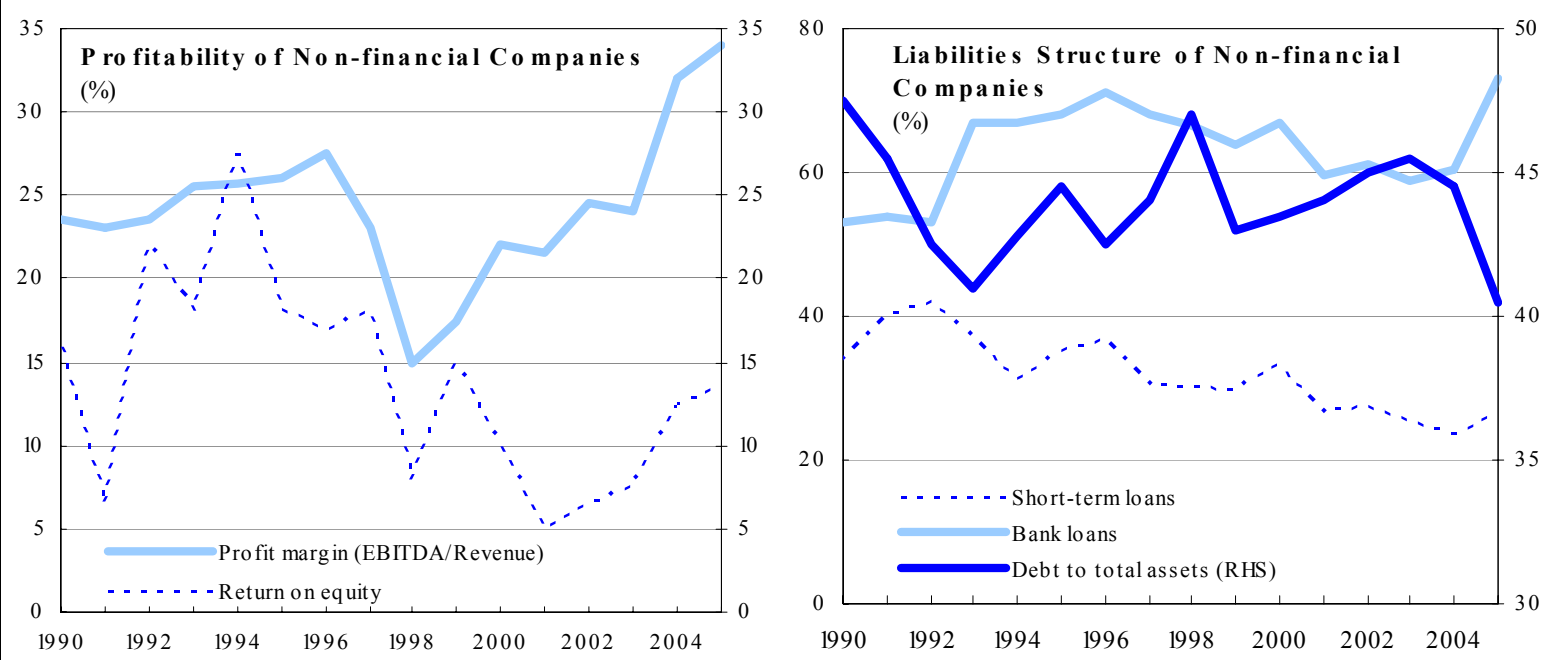

Sources: Thomson Financial, CEIC, Hong Kong SAR authorities and staff estimates. 


\begin{tabular}{|c|c|c|c|c|c|c|c|}
\hline \multicolumn{8}{|c|}{$\begin{array}{c}\text { Hong Kong SAR: Medium-Term Projections, 2005-11 } \\
\text { (Percentage change from the previous period, unless otherwise indicated) }\end{array}$} \\
\hline & 2005 & 2006 & 2007 & 2008 & 2009 & 2010 & 2011 \\
\hline Real GDP & 7.3 & 5.8 & 5.3 & 5.0 & 5.0 & 5.0 & 5.0 \\
\hline Total domestic demand & 1.9 & 6.3 & 5.9 & 5.1 & 4.9 & 4.8 & 4.7 \\
\hline Net exports (contribution) & 5.6 & 0.5 & 0.4 & 0.7 & 0.9 & 0.9 & 1.1 \\
\hline Unemployment rate (percent) & 5.6 & 4.5 & 4.0 & 3.7 & 3.5 & 3.3 & 3.2 \\
\hline $\mathrm{CPI}$ inflation & 1.0 & 2.3 & 2.5 & 2.6 & 2.7 & 2.8 & 2.8 \\
\hline \multicolumn{8}{|l|}{ Savings-investment balances $1 /$} \\
\hline Private & 10.1 & 7.3 & 5.9 & 5.3 & 4.7 & 4.1 & 3.7 \\
\hline Public & 1.3 & 2.0 & 2.6 & 3.2 & 3.7 & 4.0 & 4.3 \\
\hline Current account balance $1 /$ & 11.4 & 9.3 & 8.6 & 8.5 & 8.3 & 8.2 & 8.0 \\
\hline Goods and Services Balance 1/ & 12.5 & 10.5 & 9.3 & 8.7 & 8.1 & 7.6 & 7.2 \\
\hline Capital and financial account balance 1/ & -11.6 & -9.3 & -8.5 & -8.5 & -8.3 & -8.2 & -8.0 \\
\hline Foreign exchange reserves $1 /$ & 69.9 & 66.4 & 62.5 & 58.8 & 55.3 & 52.0 & 48.8 \\
\hline
\end{tabular}

\section{REPORT ON DISCUSSIONS}

\section{With the economy on a strong footing, this year's discussions were streamlined,} focusing on: the fiscal policy challenges of aging and volatile revenue; and enhancing competitiveness and managing the expanding financial links with the Mainland. These issues reflect the authorities' priorities as they take advantage of the current favorable environment to initiate reforms in these areas to boost medium-term prospects.

\section{A. Fiscal Policy: Looking Beyond the Good Times}

\section{Appropriately, this year's budget continues to take advantage of the strong} economy to further strengthen the fiscal position (Figure 5). Last year, strong revenue growth and expenditure restraint helped achieve the first budget surplus (of around 1 percent of GDP) since FY1999/00. The structural balance is also expected to move into surplus, appropriate for this stage of the cycle. In this year's budget, the authorities resisted calls for broad-based tax cuts and exemptions (which would have increased the budget's reliance on volatile non-tax revenue) and introduced only modest rate cuts (costing around 11/4 percent of revenue) and spending increases. On current economic and spending trends, this year's target surplus of $1 / 2$ percent of GDP could be over performed by a modest margin.

\section{Over the medium term, Hong Kong SAR faces two principal fiscal challenges:}

population aging and volatile revenue. The economy will likely face one of the steepest increases in old-age dependency within the region in coming decades. The fully-funded and privately-managed Mandatory Provident Fund (MPF) should be able to provide a growing source of retirement income for most. However, with current healthcare expenses mostly publicly funded (around 46 percent of out-patient care and about 82 percent of in-patient hospital care), age-related public health spending pressures could rise very sharply 


\section{Figure 5. Fiscal Developments}

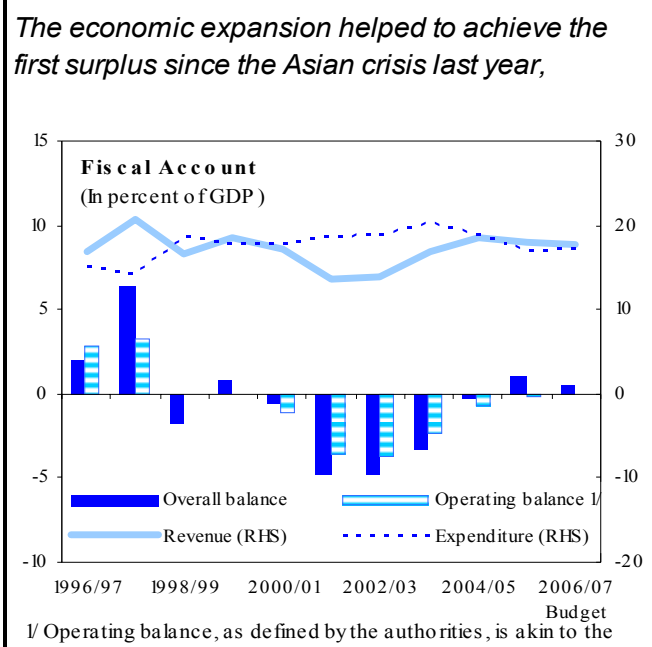

...reflecting strong revenue...

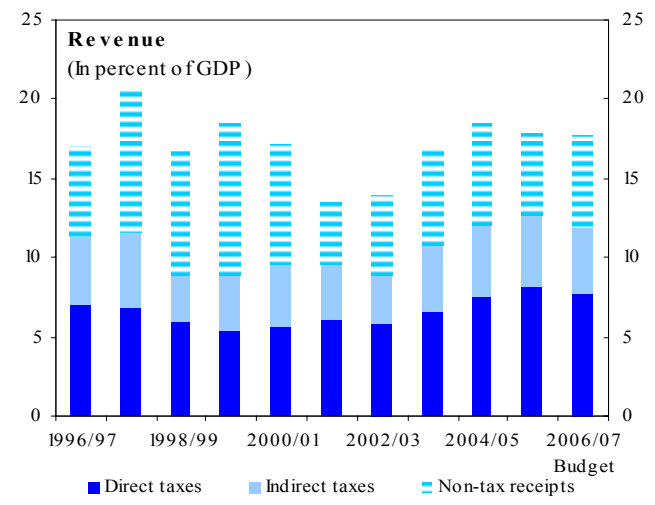
current balance.

...and restrained spending, ...

...stabilizing fiscal reserves.

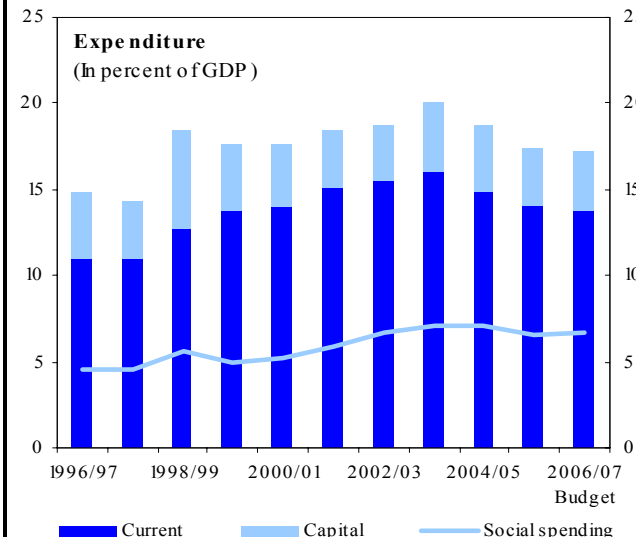

This year's budget continues the orderly withdrawal of stimulus.
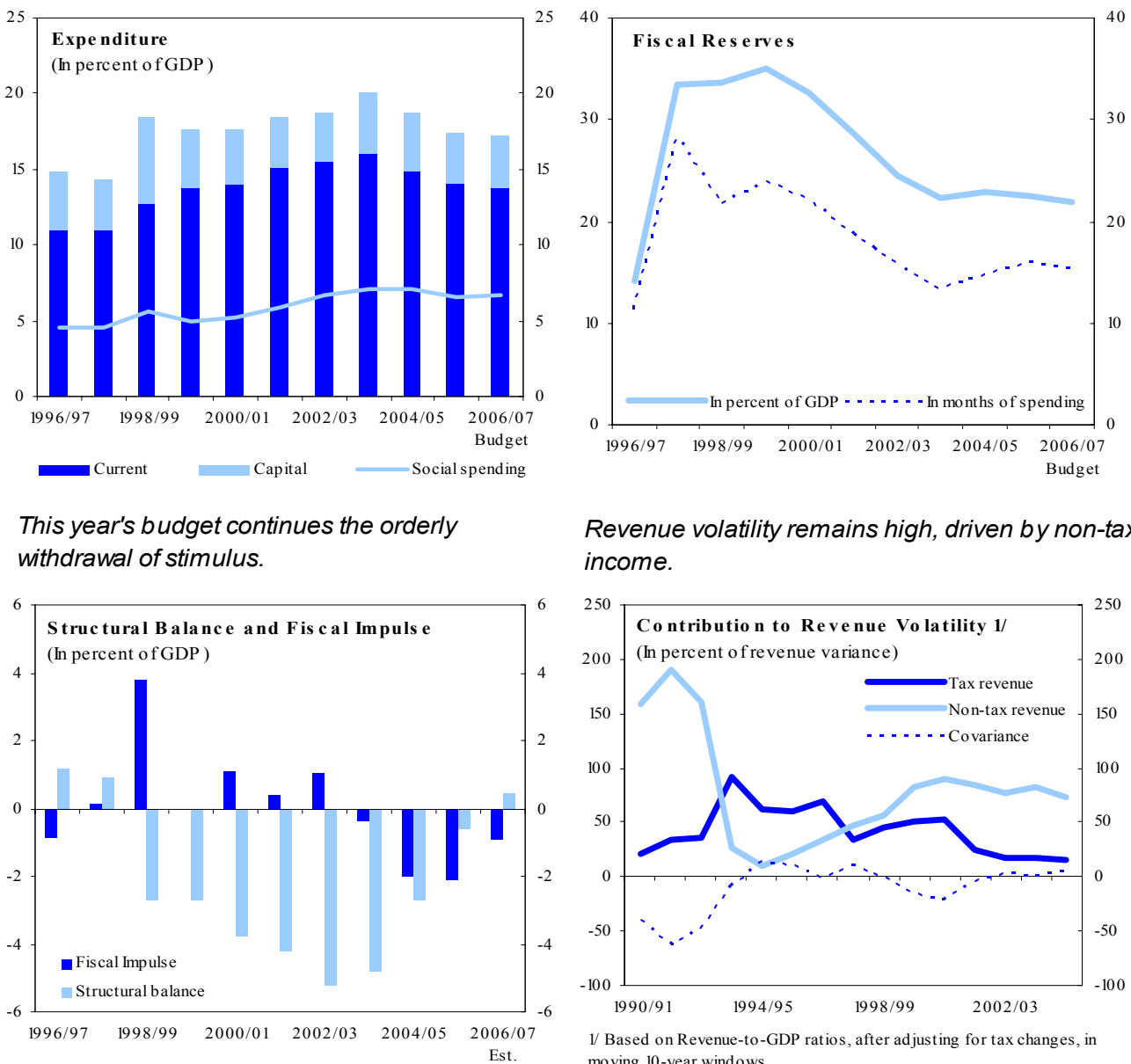

Revenue volatility remains high, driven by non-tax income.

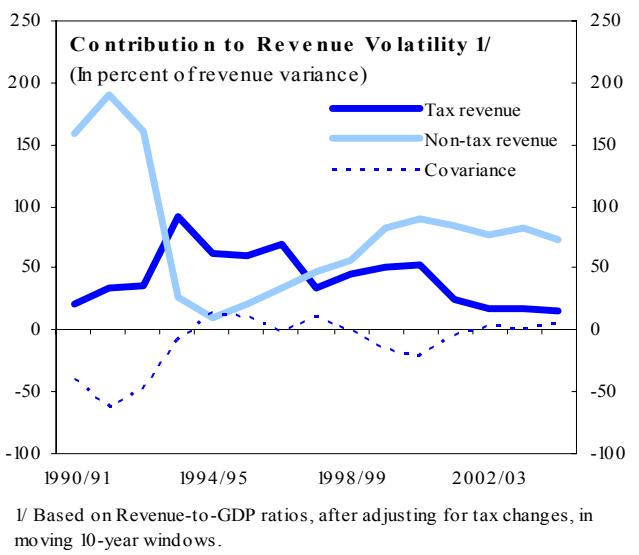

Sources: Hong Kong SAR authorities and staff estimates. 
from 2015 onwards, adding around 5-6 percentage points of GDP to spending by $2030 .^{2}$ In response, the authorities have proposed reforming healthcare delivery and financing systems. The planned reforms to the delivery system (on which public consultations were initiated last year) emphasize greater private provision of primary care, and limit the reliance on public hospitals to acute and specialized cases. Financing reform proposals are still being developed, with public consultations planned for mid-2007; options include compulsory or subsidized insurance, premium-based catastrophe coverage, and contributory schemes.

\section{Hong Kong SAR's public revenue} is one of the most volatile in the region, due to a narrow tax base and significant dependence on volatile non-tax revenues.

To address this, the authorities have launched a public consultation with the proposed introduction of a goods and services tax (GST), which the staff has long supported, as its focal point. Their proposal calls for a low-rate tax with few exemptions and a high registration threshold, in line with past staff advice. ${ }^{3}$ Staff analysis suggests that under the

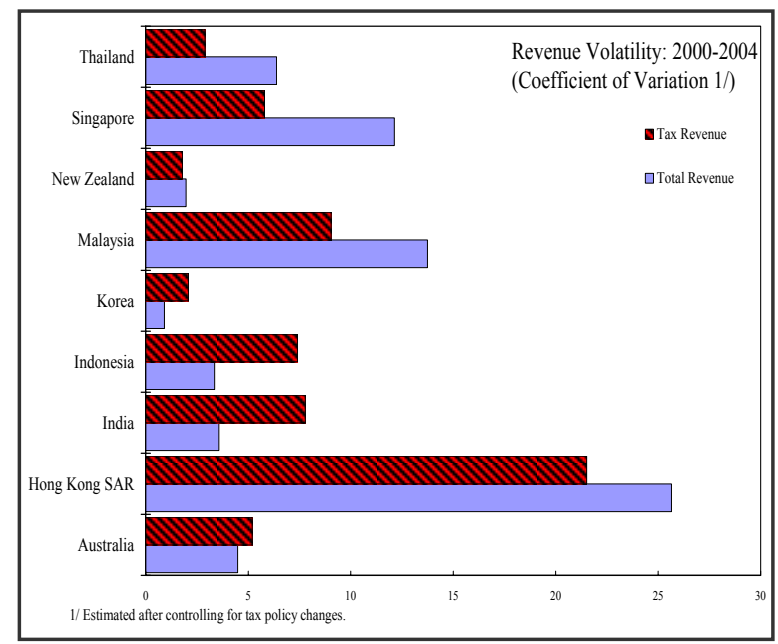
current revenue structure, significant fiscal reserves, possibly even higher than those already held, may be necessary to provide a sufficient buffer against the type of economic shocks seen over the last decade. ${ }^{4}$ A low-rated and broad-based GST, would lower the amount of reserves needed for such purposes, especially over time as the consumption-tax base is likely to expand more than the salaries-tax base due to aging. ${ }^{5}$ However, the proposed GST has run into strong public opposition. The staff met with representatives from a number of political parties that oppose the GST, who, while recognizing the need to broaden the tax base, were concerned about the lack of discussion of alternative measures, and the disproportionate burden such a tax would place on the poor. Staff pointed out that broadening compensation for low-income groups and other offsets could help to mitigate the regressive impact of the

\footnotetext{
${ }^{2}$ Leigh, L., 2006, "Hong Kong SAR: Macroeconomic Impact of an Aging Population in a Highly Open Economy,” IMF Working Paper 06/87 (Washington: International Monetary Fund).
}

${ }^{3}$ The Fund provided technical assistance on designing and implementing the GST in 2001 and 2004.

${ }^{4}$ Staff's analysis in Chapter I of the Selected Issues Paper shows that on current policies, desirable reserves could be as high as 30 percent of GDP for age-related spending and 30 percent of GDP as a buffer against revenue volatility (calculated using Value-at-Risk methodology). At present, the reserve level is just above 20 percent of GDP.

\footnotetext{
${ }^{5}$ Staff estimates indicate that with aging the consumption-tax base could grow by 40 percent more than the salaries-tax base in the coming decades, as the portion of household income from non-wage sources (reflecting large accumulated savings) becomes larger.
} 
tax. ${ }^{6}$ The authorities intend to develop more concrete alternatives to broaden the tax base, taking into account the concerns raised during the current consultation on the GST, and present them at a later date. The staff suggested that, in addition to a GST, other measures to reduce revenue volatility could be considered, such as negotiating a more stable return on government financial assets, which are managed by the Exchange Fund, compensating the latter for assuming additional risk. ${ }^{7}$

\begin{tabular}{|c|c|c|c|c|}
\hline \multicolumn{5}{|c|}{ Comparison of VAT Rates and Registration Thresholds $1 /$} \\
\hline & \multirow{2}{*}{$\begin{array}{c}\text { Standard } \\
\text { Rate at } \\
\text { Introduction }\end{array}$} & \multirow{2}{*}{$\begin{array}{c}\text { Current } \\
\text { Standard } \\
\text { Rate }\end{array}$} & \multicolumn{2}{|c|}{ Registration Threshold } \\
\hline & & & US\$ & $\begin{array}{c}\% \text { of Per Capita } \\
\text { GDP }\end{array}$ \\
\hline Hong Kong 2/ & & & 642,055 & 2,509 \\
\hline Asia and Pacific 3/ & 8.3 & 8.4 & & \\
\hline Australia & 10.0 & 10.0 & 37,159 & 107 \\
\hline Indonesia & 10.0 & 10.0 & 109,165 & 11,762 \\
\hline Japan 4/ & 3.0 & 5.0 & 86,302 & 241 \\
\hline Korea & 13.0 & 10.0 & 12,440 & 76 \\
\hline Philippines & 10.0 & 10.0 & 10,612 & 1,012 \\
\hline Singapore & 3.0 & 5.0 & 620,132 & 2924 \\
\hline Thailand & 7.0 & 7.0 & 30,964 & 1,574 \\
\hline Canada & 7.0 & 7.0 & 26,229 & 75 \\
\hline EU $3 /$ & 14.8 & 19.4 & 25,024 & 174 \\
\hline United Kingdom & 10.0 & 17.5 & 106,651 & 274 \\
\hline \multicolumn{5}{|c|}{$\begin{array}{l}\text { Sources: IMF, Fiscal Affairs Department, and staff estimates. } \\
\text { 1/ As at end-2005. } \\
\text { 2/ Government proposal. }\end{array}$} \\
\hline \multicolumn{5}{|c|}{$\begin{array}{l}\text { 3/ Unweighted average. } \\
\text { 4/ Including } 1 \text { percent local tax. }\end{array}$} \\
\hline
\end{tabular}

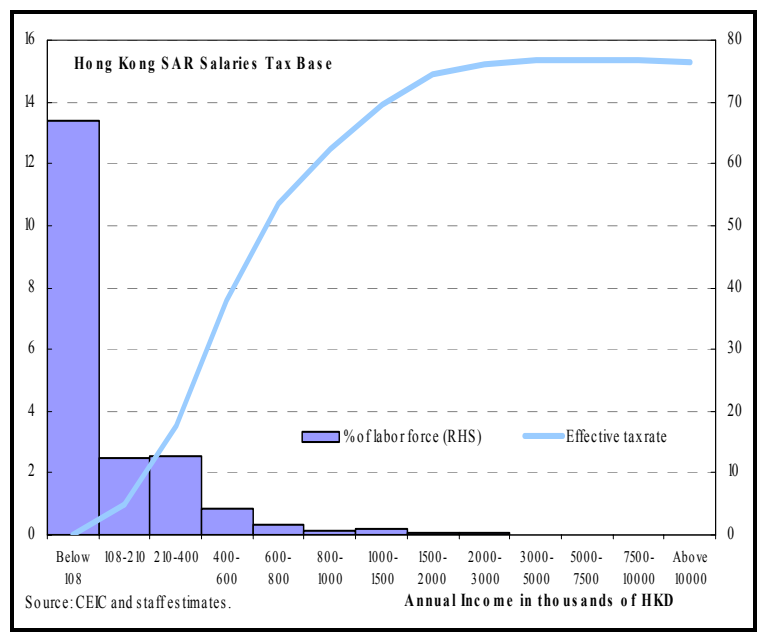

\section{B. Exchange Rate Regime: A More Resilient System}

\section{The staff reiterated their support for the authorities' commitment to the LERS.}

In the aftermath of the May 2005 refinements, renminbi-related speculation dampened as exchange rate changes against the U.S. dollar (USD) were effectively limited to a narrow band of Hong Kong dollar (HKD) 7.75-7.85 per USD (Figure 6). ${ }^{8}$ With the ebbing of appreciation pressures, HKD and USD interest rates realigned. These changes also helped the financial system absorb large capital inflows associated with lumpy IPO activity (including the USD11 billion Bank of China IPO in May and the USD16 billion ICBC IPO in October) in an orderly manner, with no intervention by the monetary authority (HKMA). Although

\footnotetext{
${ }^{6}$ Offsets proposed in the consultation paper include income tax cuts. The staff also provided examples from countries, such as Singapore, where the government, in addition to offsetting income tax cuts, distributed "Economic Restructuring Shares" at the time of raising the GST rate. These dividend-paying shares could be encashed anytime over a transitional five year period.

${ }^{7}$ Staff estimates suggest that fixing returns at their historical rate could reduce the fiscal value-at-risk by as much as 20 percent (Chapter I of the People's Republic of China - Hong Kong Special Administrative Region: Selected Issues (www.imf.org)).
}

${ }^{8}$ Details of the refinements were discussed in the 2005 Article IV Staff Report (IMF Country Report No. 06/50). 


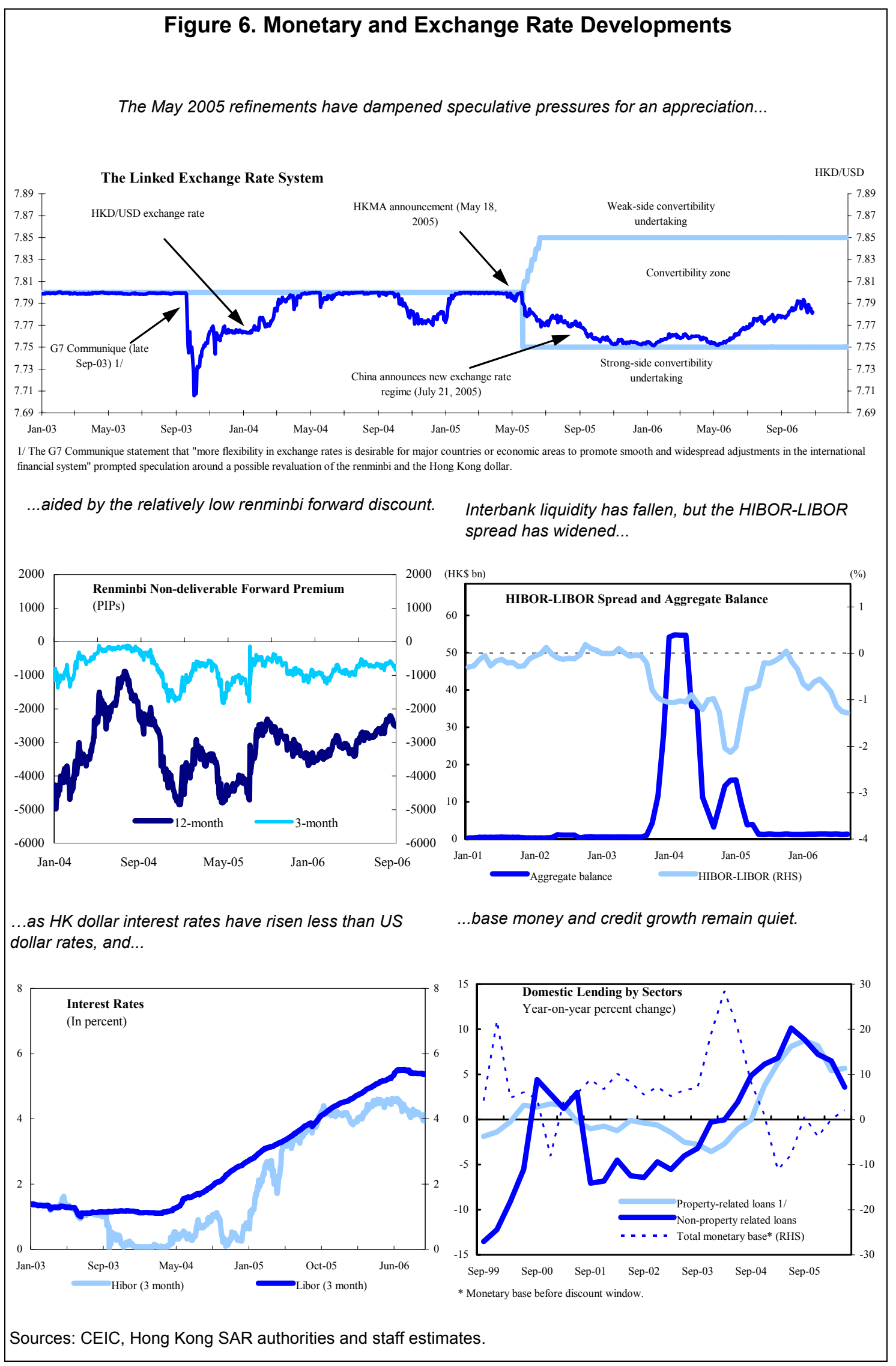

(CInternational Monetary Fund. Not for Redistribution 
the refined system has not been fully tested, it appears to be sufficiently fortified to withstand shocks, as well as potentially greater renminbi flexibility. ${ }^{9}$ The demonstrated flexibility of Hong Kong SAR's markets should facilitate adjustment over the medium term to larger or more lasting shocks. ${ }^{10}$ Notwithstanding the improved credibility of the LERS, in recent months forward markets appear to be pricing an appreciation of the HKD outside the strongside convertibility rate (beyond a three month horizon), with HKD interest rates drifting below comparable USD interest rates. Market analysts, bankers, and the authorities attributed this to high HKD liquidity in the banking system related to several factors, including large IPOs. The staff noted that while this was not necessarily a matter of immediate policy concern, a risk was that the HKD-USD interest rate gap could close suddenly, putting pressure on some banks' interest margins.
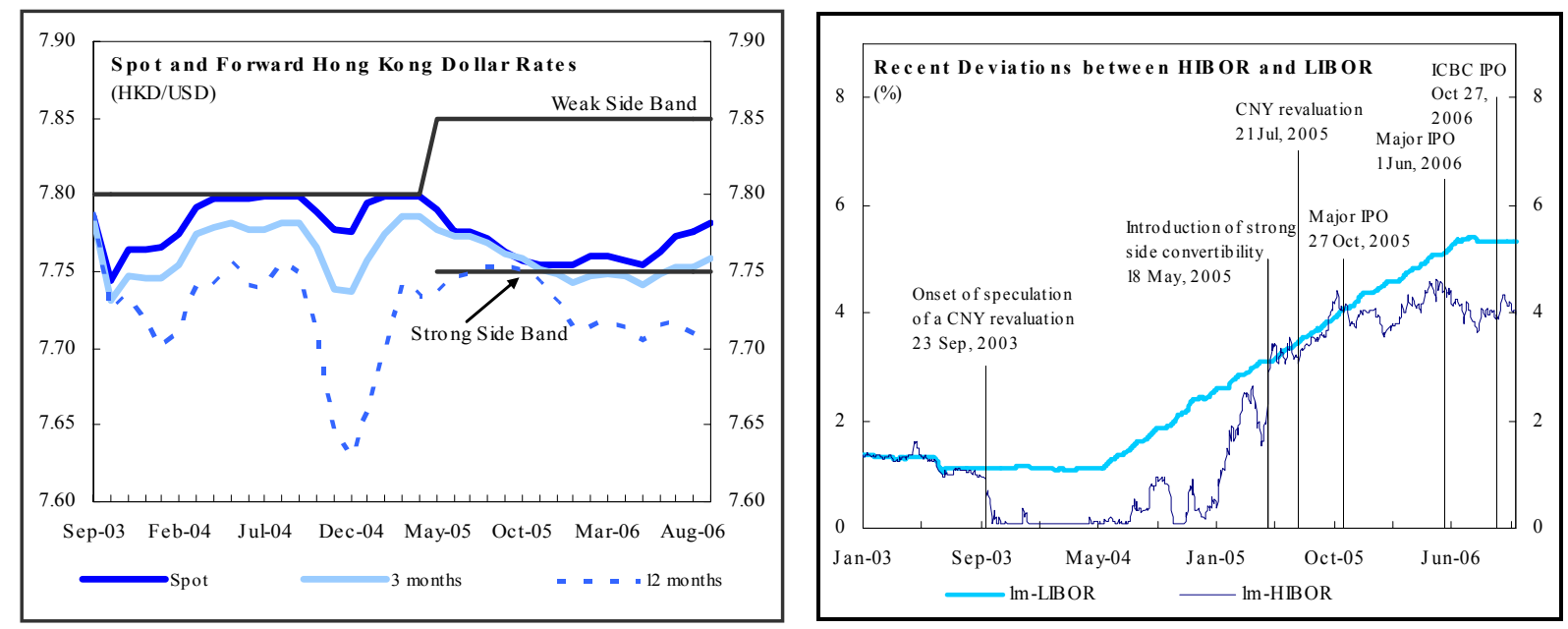

\footnotetext{
${ }^{9}$ The impact of a sizable renminbi appreciation will depend on its impact on China's exports. A decline in China's export growth would lower Hong Kong SAR's re-export growth, but improve the competitiveness of its domestic goods and services exports. On balance, a 5-10 percent appreciation of the renminbi should have a small impact on Hong Kong SAR in the near term.
}

${ }^{10}$ A recent HKMA study simulated a number of China-related shocks, such as a rise in protectionist sentiment and financial instability. Although the magnitude of these shocks is large, in most cases representing more than two-standard deviations of historical volatility, the simulated impact on Hong Kong SAR is moderate. For example, a 20 percentage point decline in China's export growth in one year slows Hong Kong SAR's GDP growth by 6 percentage points over two years. None of the simulated shocks resulted in a slowdown similar to that during the Asian crisis, when growth fell more than 10 percentage points in the first year. 


\section{Competitiveness: Building on Traditional Strengths and Financial Development}

\section{Hong Kong SAR's external price competitiveness has improved over the past} few years (Figures 7 and 8). ${ }^{11}$ Given the LERS, adjustment to macroeconomic imbalances and external shocks has taken place through changes in the real exchange rate driven by the price flexibility of domestic markets.

Following prolonged deflation, these prices now have all turned around, indicating that adjustment to the shocks of the last few years is over. At present, goods and wage inflation is low, equity prices have risen in line with earnings, and property prices have stabilized. Stable price increases across goods, labor, and asset markets suggest that price competitiveness is broadly in line with fundamentals. The continued large
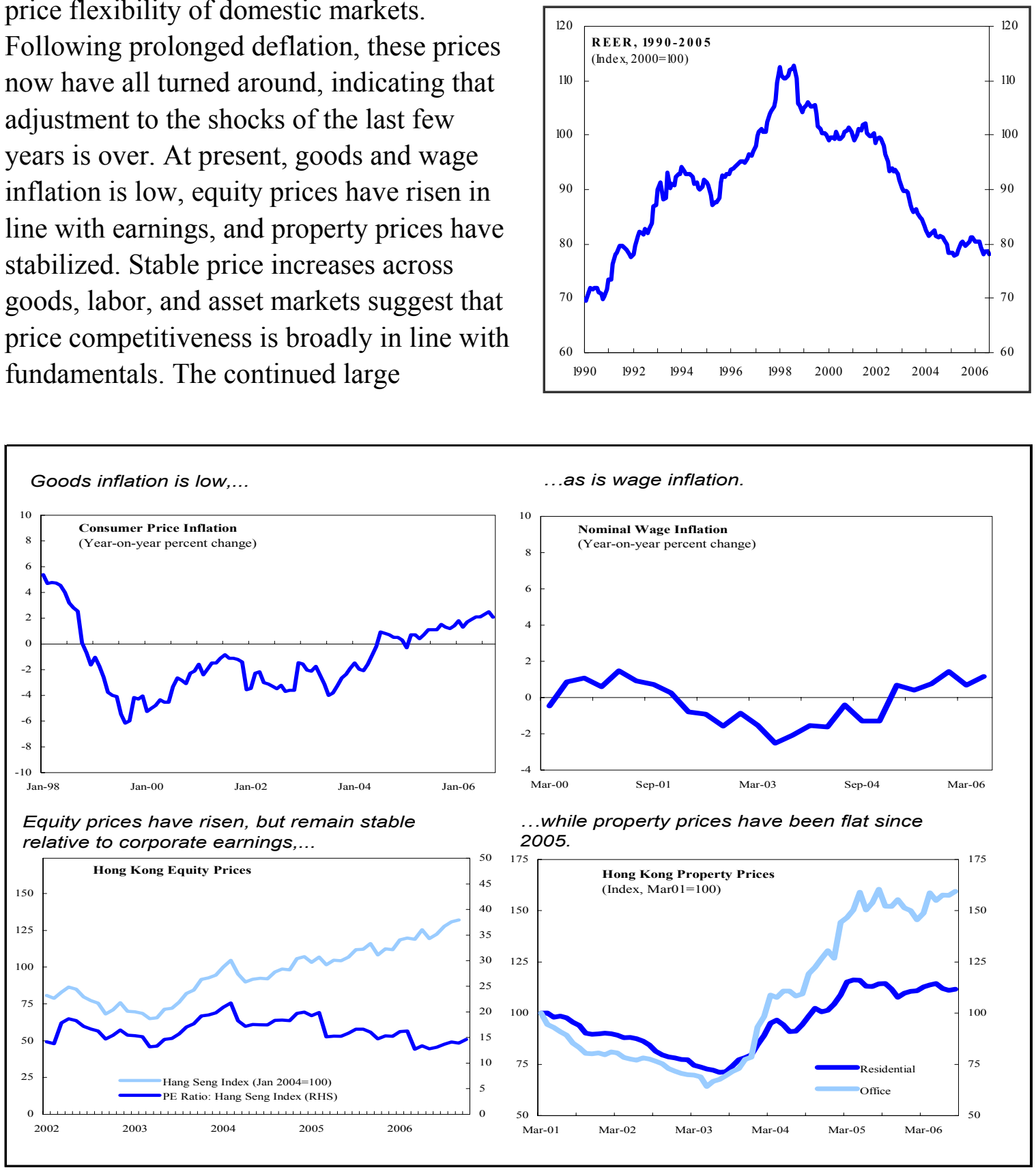

\footnotetext{
${ }^{11}$ See Chapter II of the People's Republic of China - Hong Kong Special Administrative Region: Selected Issues (www.imf.org).
} 
Figure 7. Hong Kong SAR's Balance of Payments Dynamics

Reflecting economic restructuring, the composition of the current account and the balance of payments has also changed.

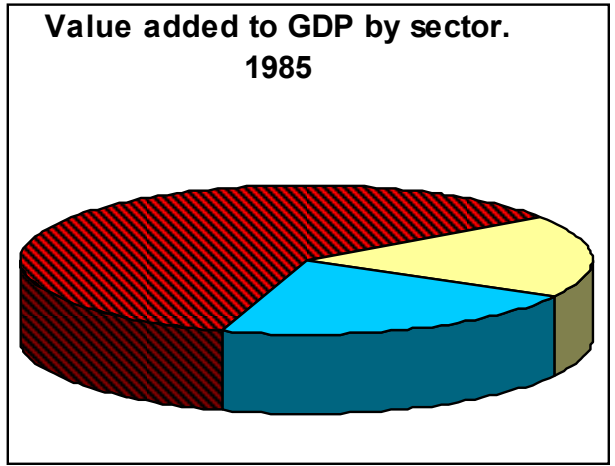

$\square$ Manufacturing

Services

$\square$ Other

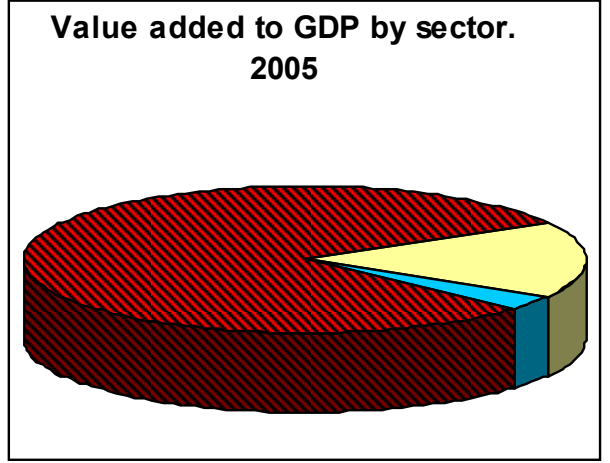

$\square$ Manufacturing

Services

$\square$ Other

Current Account Composition

(In percent of GDP)

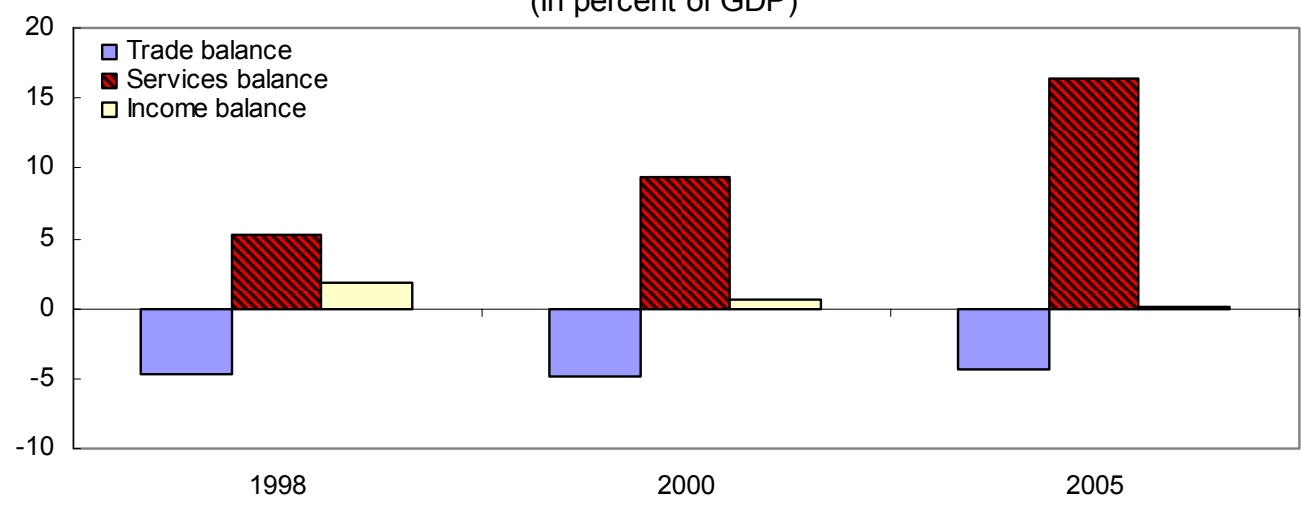

Balance of payments flows

(In percent of GDP)

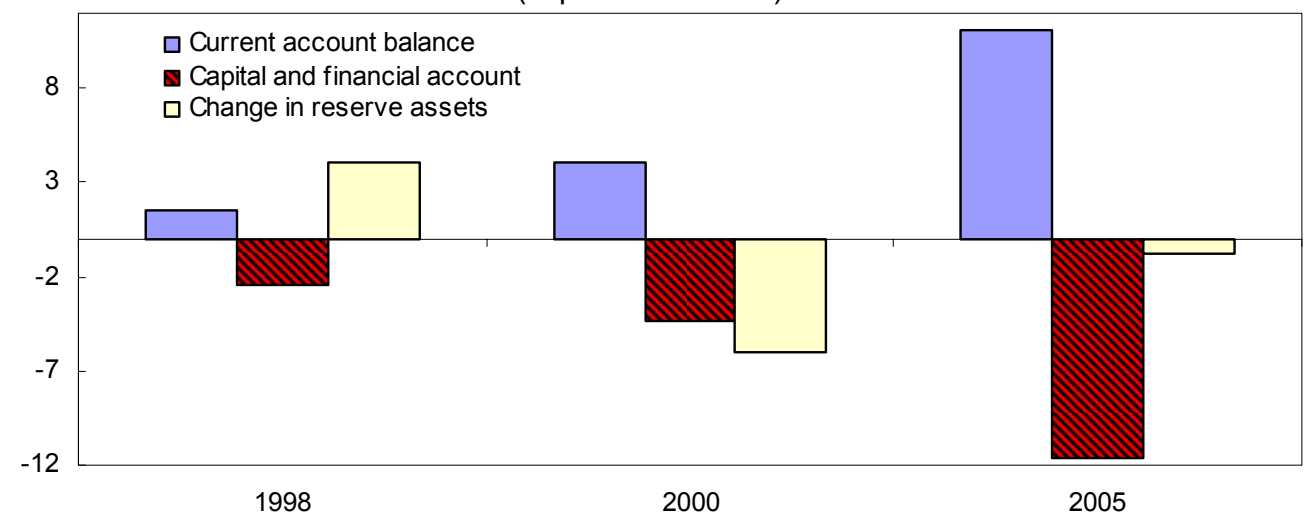

Sources: CEIC, Hong Kong SAR authorities, and staff estimates. 
Figure 8. Trends in Competitiveness

With the post-Asian crisis adjustment complete, the REER has returned to its pre-crisis level.

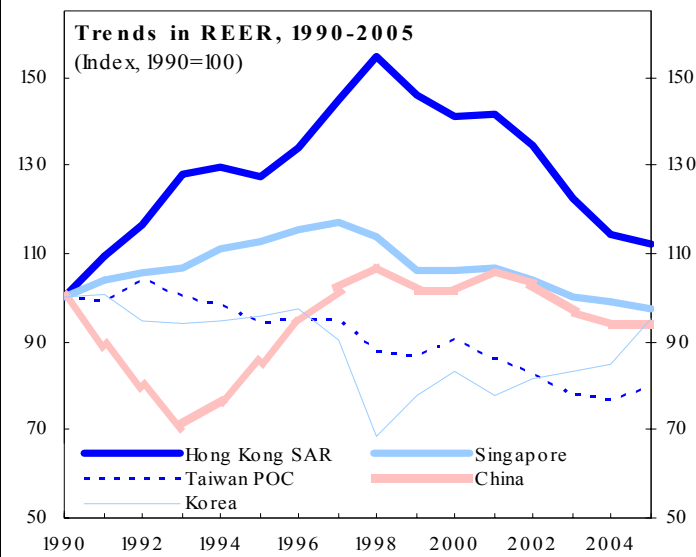

In the labor market, wages fell relative to productivity...

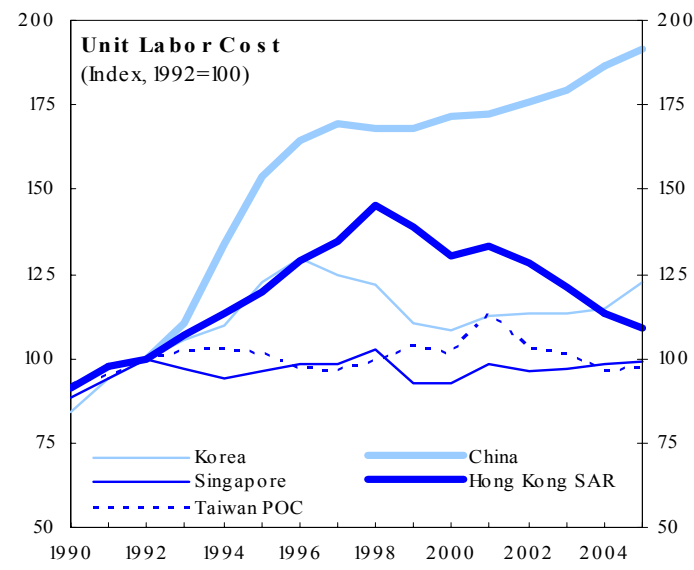

Property prices have also grown less rapidly than in many other regional cities.

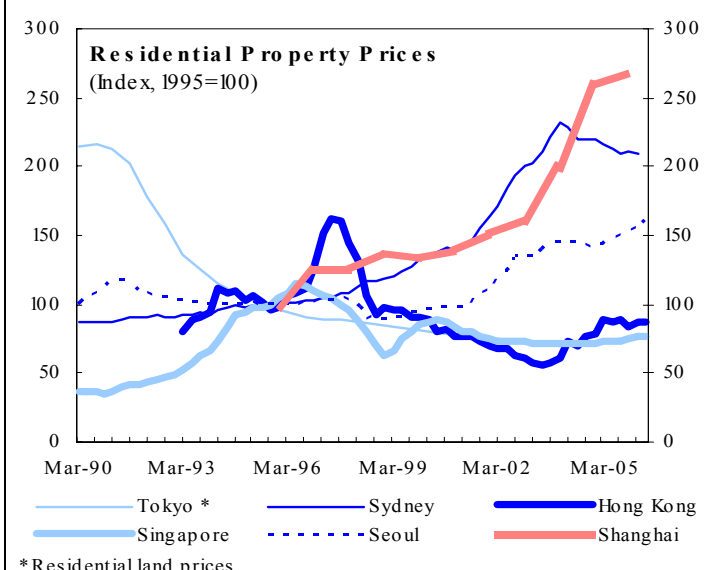

*Residential land prices
This adjustment required a long deflation which realigned relative prices in the product market.

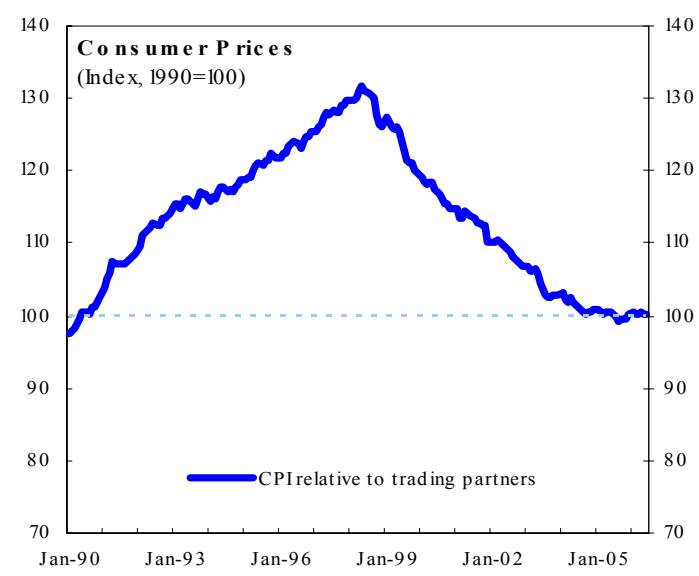

...particularly in financial services.

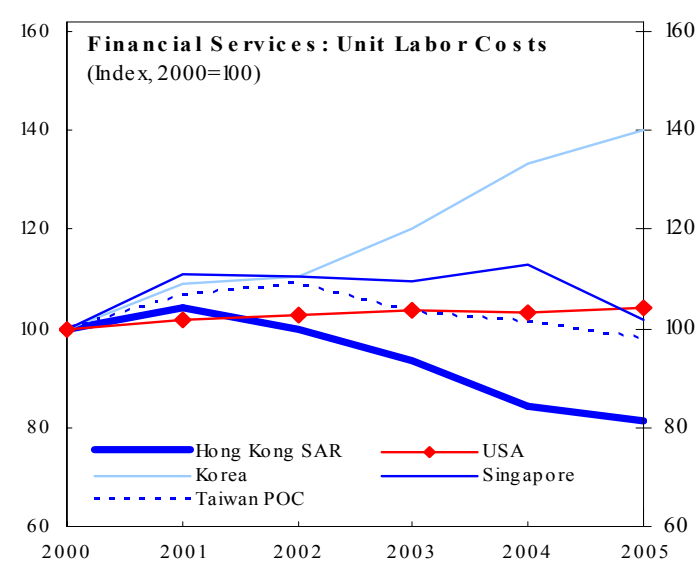

But the SAR has slipped in some rankings of competitiveness due to non-price factors.

Hong Kong SAR's Growth $\mathrm{C}_{\mathrm{a}} \rho$ mpetitiveness Rankings

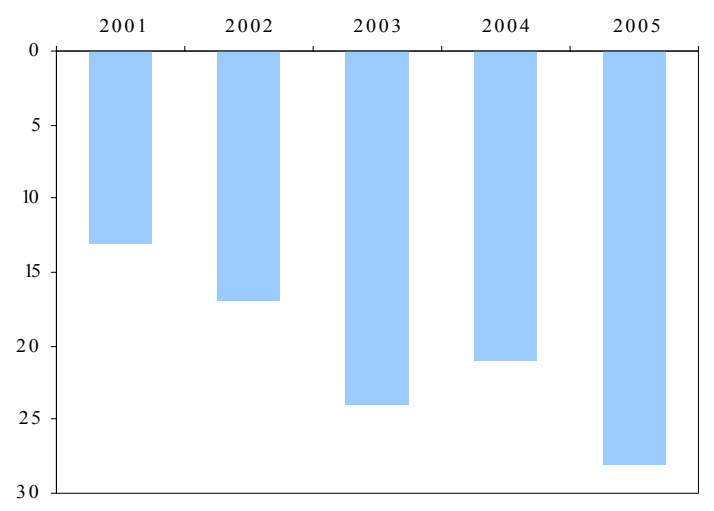

Source: World Economic Forum

Source: CEIC, World Economic Forum, Hong Kong SAR authorities and staff estimates. 
current account surplus largely reflects the economic restructuring of the past few years when outward FDI increased as domestic investors relocated existing operations and sought new business opportunities in the Mainland. These trends are unlikely to be reversed any time soon. Thus, over the medium term, the merchandise trade balance will remain in deficit, while the current account continues to generate substantial surpluses reflecting earnings from foreign investments, tourism, and trade and financial intermediation, with the net international investment position (currently $3 \frac{1}{2}$ times the size of foreign reserves and $2 \frac{1}{2}$ times GDP) strengthening further.

\section{Beyond the improvement in price competitiveness, Hong Kong SAR's} traditional strengths - flexible markets and strong institutions- - have been and will remain key to the economy's attractiveness as an international business hub. In response to growing calls for a legislated minimum wage, the authorities have begun a voluntary "wage protection movement" for two specific low-wage occupations. The staff reiterated that legislating a minimum wage is a social compact and, when properly designed, should not unduly affect employment. However, as institutional constraints on macroeconomic policies have placed much of the burden of economic adjustment on the flexibility of nominal wages and other prices, care needs to be taken that such legislation does not impair this flexibility and the economy's competitiveness. In this regard, key considerations include the initial level of the minimum wage, how it is adjusted over time, the extent of differentiation across the age distribution of the working population, and how it interacts with the tax and in-work benefits system. ${ }^{12}$ Enhancing in-work benefits have been demonstrated elsewhere to be effective in improving the conditions of the working poor, and strengthening existing social safety net programs could help to alleviate poverty among non-working households. Separately, staff welcomes the recent decision to begin a three month public consultation on a general competition law, an initiative it has long supported.

\section{In discussions with staff, concerns were raised about the adverse impact of} increased pollution on competitiveness. Many private sector representatives noted that the increase in pollution made attracting and retaining high-skilled workers more difficult, especially given the tight labor market. While there was broad support for the government's growing recognition of these concerns and efforts to address them, many felt that initiatives to reduce cross-border pollution could be speeded up and that greater emphasis could be placed on market-based mechanisms to reduce pollution.

\footnotetext{
${ }^{12}$ For details see Box 2 in the 2005 Article IV Staff Report (IMF Country Report No. 06/50).
} 
Figure 9. Growing Integration with the Mainland

Mainland firms are increasingly using Hong Kong SAR's markets to raise capital...

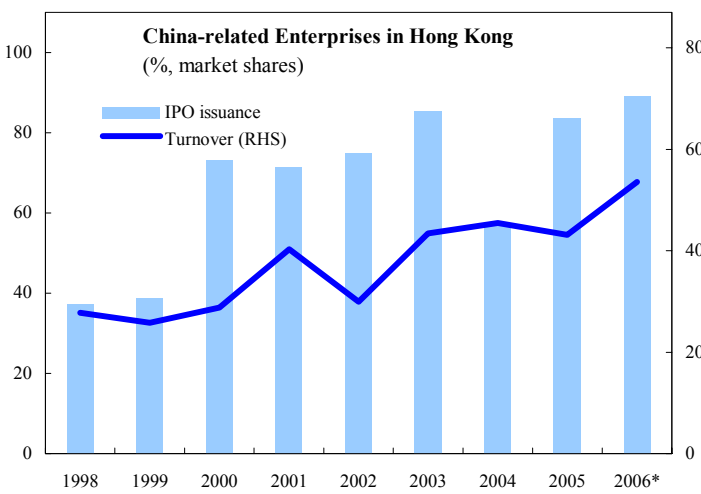

* 2006 turnover and IPO issuance is annualized using data up to September

While renminbi business is still is in its infancy, renminbi banking,...

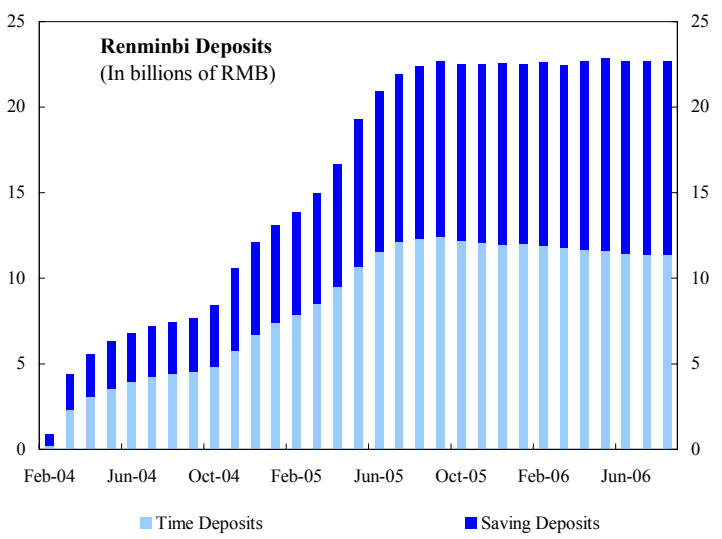

Hong Kong banks are also increasing their Mainland exposure.

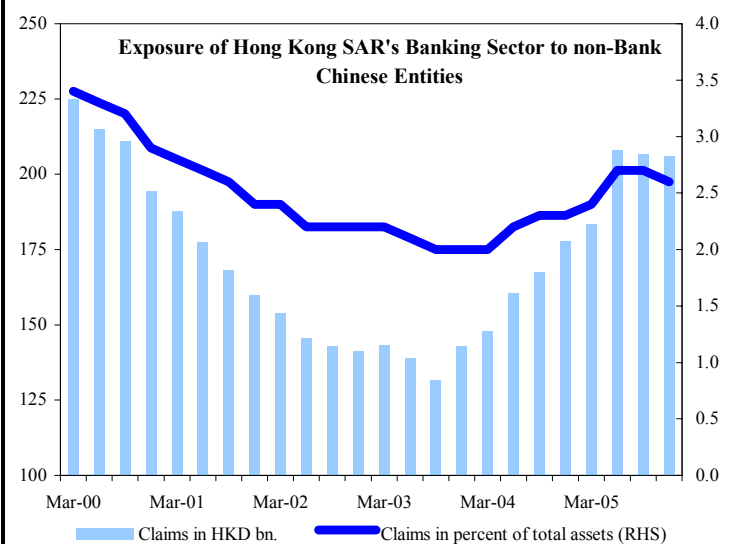

...and income from Mainland investments has also increased.

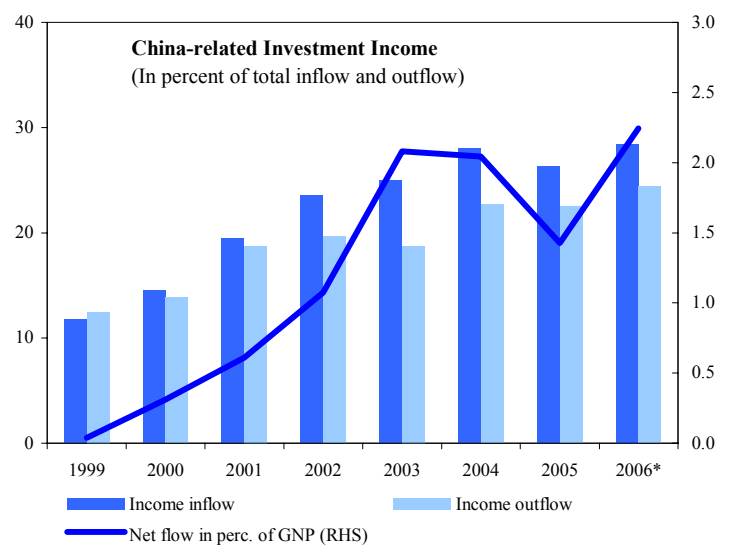

...and remittances to the Mainland have expanded in recent years.

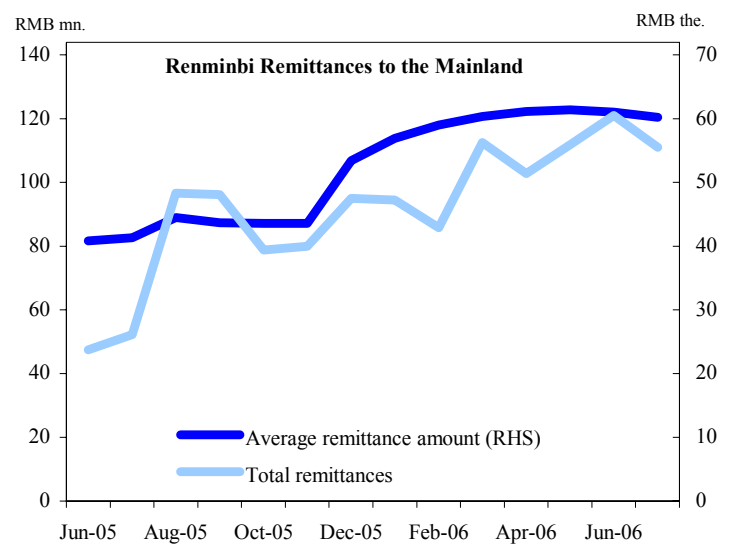

Air and land trade-related services have replaced port services that have grown rapidly on the Mainland.

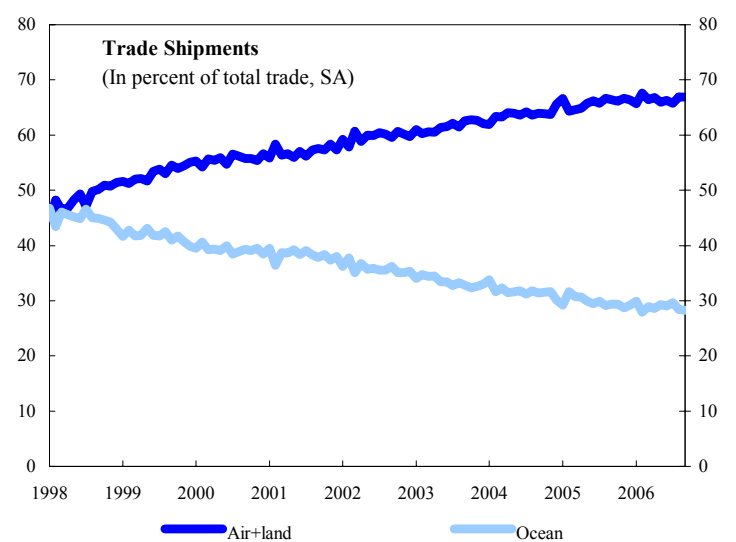

Sources: CEIC, Hong Kong SAR authorities, and staff estimates. 


\section{There was broad agreement that, in the coming years, increased financial} integration with the Mainland would be a major driver of Hong Kong SAR's economic prospects (Figure 9). ${ }^{13}$ Fundraising by Mainland-related firms reached new heights this year, while arrangements under CEPA have opened up opportunities for Hong Kong service suppliers, and the easing of controls on outward capital flows by the Mainland should boost the Hong Kong wealth management sector over time. Hong Kong SAR's capital market has also deepened with the expansion of existing financial instruments, such as equityderivatives, and the introduction of both exchange traded and over-the-counter Mainlandrelated non-deliverable products. Together with renminbi business, these are positive signs, but both the government and the market considered increasing the SAR's role in the direct intermediation of the Mainland's domestic savings as key for the continued success of its financial center. The staff noted that allowing Mainland financial institutions to issue renminbi-denominated bonds in Hong Kong SAR - a proposal that awaits approval by China's State Council — was a good example of how Hong Kong SAR's financial infrastructure could be used to benefit both economies. The authorities added that discussions were ongoing with Mainland authorities on other ways to use Hong Kong SAR's infrastructure in China's financial intermediation.

\begin{tabular}{|c|c|c|c|c|c|c|c|c|}
\hline \multicolumn{9}{|c|}{$\begin{array}{l}\text { Net External Transactions of Hong Kong SAR with Mainland China } \\
\text { (Net inflows (+)/outflows (-); billions of US\$) }\end{array}$} \\
\hline & 1998 & 1999 & 2000 & 2001 & 2002 & 2003 & 2004 & 2005 \\
\hline Goods Trade & 17.9 & 12.1 & 14.5 & 17.6 & 18.8 & 25.2 & 31.5 & 34.3 \\
\hline Services Trade & 0.4 & 0.5 & 1.2 & 2.2 & 4.4 & 5.7 & 6.7 & 8.1 \\
\hline Investment Income & 0.4 & 0.1 & 0.5 & 1.0 & 1.8 & 3.3 & 3.5 & 2.6 \\
\hline Direct Investment & -15.9 & -11.3 & -1.3 & -11.8 & -13.8 & -12.8 & -11.0 & -9.5 \\
\hline Portfolio Investment & -0.5 & -0.5 & -6.7 & -0.9 & -2.3 & -6.2 & -7.7 & -20.4 \\
\hline
\end{tabular}

\section{The authorities consider preserving} financial stability to be crucial in safeguarding competitiveness, especially as capital markets expand and new businesses emerge. At present, banks remain well capitalized and profitable, a deposit insurance scheme was introduced in September, and progress towards adopting Basel II standards is proceeding well. The authorities noted that the expansion of equity-linked derivatives has not

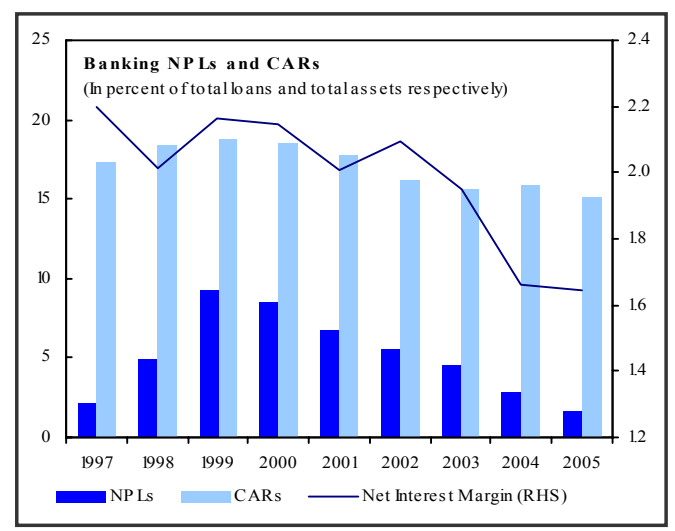

\footnotetext{
${ }^{13}$ See Chapter III of the People's Republic of China - Hong Kong Special Administrative Region: Selected Issues (www.imf.org).
} 
systemically affected volatility in the main equity markets. Nonetheless, they have increased market risk monitoring, tightened issuance rules, and increased transparency. The Hong Kong Exchanges and Clearing Limited (HKEX) is also reviewing listing rules to allow firms incorporated in many other jurisdictions to list domestically. As high listing standards, along with market depth, have been an important reason why firms have sought out listing in Hong Kong SAR, the authorities noted that it is not in their interest to dilute these standards in the review. The authorities are continuing to expand coordination with Mainland authorities in monitoring cross-border risks, especially with the growth in Mainland-related business. They also consider the financial center's reputation for good governance as another pillar supporting its competitiveness. In this regard, AML/CFT enforcement is being broadened, beyond the present regulator-specific coverage, through a more comprehensive legislative framework. The authorities are also reviewing the Companies Ordinance to reduce business compliance costs and strengthen corporate governance, and are creating an independent Financial Reporting Council to investigate auditing and reporting irregularities.

\section{Staff AppraisaL}

\section{After three years of rapid economic growth, the pace of activity is expectedly} moderating. A strong external environment, the flexibility of Hong Kong SAR's markets, along with skillful macroeconomic management and a strengthening of financial market infrastructure, were key factors in the turnaround over the last three years. Staff expects growth to continue, but at a somewhat slower pace, with the main near-term risk being a sharp slowdown in global demand. Over the medium term, much will depend on how well the evolving financial integration with the Mainland is managed and expanded, and competitive pressures from other regional financial centers withstood.

\section{Appropriately, this year's budget continues to take advantage of the strong} economy to further strengthen the fiscal position. While there is little current risk to fiscal sustainability, over the medium term the budget will likely face rising age-related spending pressures, and continued revenue volatility will have to be managed. The authorities are judiciously using the space provided by the current favorable economic environment to focus on reforms to the healthcare system and initiating public consultations on ways to broaden the tax base. The staff has long considered a low-rated and broad-based Goods and Services Tax to be an efficient way to broaden the tax base, using targeted compensation to alleviate the resulting burden on low-income households. In addition to a GST, the government could seek ways to stabilize investment income through arrangements with the Exchange Fund.

\section{The staff reiterates its support for the authorities' commitment to the LERS.}

The May 2005 refinements have strengthened the LERS, and although the refined system has not been fully tested, it appears to be sufficiently fortified to withstand shocks, as well as potential greater renminbi flexibility. 
17. The authorities are appropriately focusing on safeguarding Hong Kong SAR's traditional strengths - flexible markets and strong institutions-which have underlined the economy's competitiveness. The envisaged competition policy law will enhance these strengths, while the design of labor market regulation needs to ensure that the balance between market flexibility and adequate worker protection is maintained.

18. In coming years, financial integration with the Mainland will be a major driver of Hong Kong SAR's economic prospects. The government is making commendable efforts to coordinate with the Mainland authorities on ways of using Hong Kong SAR's advanced financial infrastructure to improve China's financial intermediation, thereby benefiting both economies. While much will depend on the pace of China's financial liberalization, the recent proposal to have Mainland financial institutions issue renminbi denominated bonds in Hong Kong SAR is a good example of such coordination.

\section{Reinforcing its reputation for strong market infrastructure and supervision is} key to Hong Kong SAR's future as a financial center. Good progress is being made on cross-border cooperation and preparations for Basel II, while the introduction of the deposit insurance scheme should further strengthen the already sound banking system. The Securities and Futures Commission has also been proactive in assessing potential sources of stress in equity markets, including in the fast growing derivatives market, while corporate governance is being strengthened. Ensuring AML/CFT compliance is important to preserving Hong Kong SAR's reputation as a financial center and the authorities' plans to broaden enforcement through a comprehensive legislative framework are welcome.

20. It is recommended that the next Article IV consultation discussions take place in accordance with the standard 12-month cycle. 
Table 1. Hong Kong SAR: Selected Economic and Financial Indicators, 2003-2007

Nominal GDP (2005): $\quad$ US\$ 177.7 billion

Main domestic exports (percent of total, 2005): textiles and clothing (56); electronic products (33)

GDP per capita (2005): US\$25,600

Unemployment Rate (Sep 2006): 4.7 percent

FDI (2005): US\$ 3.3 billion

Public Debt (2005): 1.9 percent of GDP

Foreign public debt (2005): 0.9 percent of GDP

\begin{tabular}{|c|c|c|c|c|c|c|c|}
\hline & \multirow[b]{2}{*}{2003} & \multirow[b]{2}{*}{2004} & \multirow[b]{2}{*}{2005} & \multicolumn{2}{|c|}{2006} & \multicolumn{2}{|c|}{ Staff Proj. } \\
\hline & & & & Q1 & Q2 & 2006 & 2007 \\
\hline Real GDP (percent change) & 3.2 & 8.6 & 7.3 & 8.0 & 5.2 & 5.8 & 5.3 \\
\hline \multicolumn{8}{|l|}{ Contribution } \\
\hline Domestic demand & 0.1 & 4.7 & 1.7 & 5.7 & 4.5 & 5.3 & 4.9 \\
\hline Private consumption & -0.5 & 4.1 & 1.9 & 2.5 & 2.7 & 2.8 & 2.7 \\
\hline Government consumption & 0.2 & 0.1 & -0.3 & 0.1 & -0.1 & 0.1 & 0.0 \\
\hline Gross fixed capital formation & 0.2 & 0.8 & 1.0 & 1.8 & 1.0 & 2.4 & 2.2 \\
\hline Inventories & 0.3 & -0.2 & -0.8 & 1.4 & 0.8 & 0.0 & 0.0 \\
\hline Net exports & 3.1 & 3.9 & 5.6 & 2.3 & 0.8 & 0.5 & 0.4 \\
\hline \multicolumn{8}{|l|}{ Inflation (percent change) } \\
\hline Consumer prices & -2.6 & -0.4 & 1.0 & 1.6 & 2.0 & 2.3 & 2.5 \\
\hline GDP deflator & -6.4 & -3.6 & -0.2 & -0.1 & -0.1 & 0.0 & 1.3 \\
\hline Employment (percent change) & -0.4 & 2.8 & 2.3 & 2.0 & 1.8 & 2.9 & 2.2 \\
\hline Unemployment rate (percent, period average) $1 /$ & 7.9 & 6.8 & 5.6 & 5.2 & 5.0 & 4.5 & 4.0 \\
\hline Real wages (period average) & 0.2 & -1.2 & -0.4 & -0.7 & -0.7 & $\cdots$ & $\cdots$ \\
\hline \multicolumn{8}{|l|}{ Government budget (percent of GDP) 2/ } \\
\hline Revenue & 16.8 & 18.4 & 17.9 & $\ldots$ & $\ldots$ & 17.7 & 17.5 \\
\hline Expenditure & 20.1 & 18.8 & 16.9 & $\ldots$ & $\ldots$ & 17.2 & 16.8 \\
\hline Consolidated budget balance & -3.3 & -0.3 & 1.0 & $\ldots$ & $\ldots$ & 0.6 & 0.7 \\
\hline Fiscal reserves as of March 31 & 22.3 & 22.9 & 22.5 & $\ldots$ & $\ldots$ & 21.8 & 21.2 \\
\hline \multicolumn{8}{|l|}{ Money and credit (percent change, end-period) } \\
\hline Narrow money (M1) & 39.8 & 17.2 & -10.3 & -5.5 & 2.1 & $\ldots$ & $\ldots$ \\
\hline Broad money (M3) & 8.3 & 8.6 & 5.2 & 8.6 & 11.3 & $\ldots$ & $\ldots$ \\
\hline Loans for use in Hong Kong SAR & -2.0 & 4.9 & 7.7 & 5.9 & 4.8 & $\ldots$ & $\ldots$ \\
\hline \multicolumn{8}{|l|}{ Interest rates (percent, end-period) } \\
\hline Best lending rate & 5.0 & 5.0 & 7.8 & 8.0 & 8.0 & $\ldots$ & $\ldots$ \\
\hline Three-month HIBOR & 0.1 & 0.3 & 4.2 & 4.4 & 4.5 & $\ldots$ & $\ldots$ \\
\hline \multicolumn{8}{|l|}{ Asset prices } \\
\hline Hang Seng stock index (period average, 1964=100) & 10,346 & 12,988 & 14,402 & 15,826 & 16,262 & $\ldots$ & $\ldots$ \\
\hline Hang Seng stock index (percent change) & 0.2 & 25.5 & 10.9 & 14.6 & 16.2 & $\ldots$ & $\ldots$ \\
\hline Residential property prices (percent change) & -11.9 & 26.6 & 17.9 & 1.8 & -1.4 & $\ldots$ & $\ldots$ \\
\hline \multicolumn{8}{|l|}{ Merchandise trade (percent change) } \\
\hline Export volume & 14.0 & 15.3 & 11.4 & 14.6 & 6.3 & 6.9 & 5.5 \\
\hline Import volume & 12.8 & 14.1 & 8.5 & 13.9 & 6.7 & 7.9 & 6.7 \\
\hline \multicolumn{8}{|l|}{ External balances (percent of GDP) } \\
\hline Merchandise trade balance & -3.6 & -5.6 & -4.3 & -8.6 & -10.1 & -7.7 & -10.5 \\
\hline Domestic exports & 9.9 & 9.8 & 9.9 & 10.0 & 10.0 & 12.5 & 13.5 \\
\hline Re-exports & 131.8 & 147.2 & 153.1 & 145.4 & 158.4 & 156.2 & 157.5 \\
\hline Imports & 145.4 & 162.6 & 167.2 & 163.9 & 178.6 & 176.4 & 181.5 \\
\hline Current account & 10.4 & 9.5 & 11.4 & 10.6 & 4.4 & 9.3 & 8.6 \\
\hline \multicolumn{8}{|l|}{ Foreign exchange reserves $3 /$} \\
\hline In billions of U.S. dollars, end of period & 118.4 & 123.6 & 124.3 & 125.8 & 126.6 & $\ldots$ & $\ldots$ \\
\hline In months of retained imports & 23.3 & 21.2 & 19.8 & 19.1 & 18.4 & $\ldots$ & $\ldots$ \\
\hline In percent of broad money (M3) & 23.9 & 23.0 & 21.9 & 21.4 & 21.0 & $\ldots$ & ... \\
\hline \multicolumn{8}{|l|}{ Exchange rate } \\
\hline Linked rate (fixed) & & & $\mathrm{HK} \$ 7.80 /$ & $S \$ 1$ & & & \\
\hline Market rate $(\mathrm{HK} \$ / \cup S \$ 1$, period average) & 7.787 & 7.788 & 7.777 & 7.758 & 7.758 & $\ldots$ & $\ldots$ \\
\hline Real effective rate (period average, $2000=100$ ) & 87.0 & 81.2 & 79.5 & 80.4 & 78.7 & $\ldots$ & $\ldots$ \\
\hline
\end{tabular}

Sources: Data provided by the Hong Kong SAR authorities; and staff estimates and projections.

1/ Seasonally adjusted for Q1 and Q2 2006.

2/ Authorities' FY2006/07 Budget estimates.

3/ Includes Land Fund assets from 1997 (US\$17.5 billion at end-1997). 
Table 2. Hong Kong SAR: Standard Vulnerability Indicators

\begin{tabular}{|c|c|c|c|c|c|c|c|c|}
\hline & 2000 & 2001 & 2002 & 2003 & 2004 & 2005 & \multicolumn{2}{|c|}{ 2006-latest } \\
\hline \multicolumn{9}{|l|}{ Public Sector } \\
\hline Fiscal deficit (in percent of GDP) & -0.6 & -4.9 & -4.8 & -3.3 & -0.3 & 1.0 & $\ldots$ & \\
\hline Accumulated fiscal surplus (in percent of GDP) & 32.7 & 28.7 & 24.4 & 22.3 & 22.9 & 22.5 & 21.7 & Jul \\
\hline \multicolumn{9}{|l|}{ External Sector } \\
\hline Total Export volume (percent change) & 17.1 & -3.3 & 8.6 & 14.0 & 15.3 & 11.4 & 6.4 & Jun \\
\hline Domestic exports & 7.5 & -10.2 & -11.3 & -7.4 & 2.4 & 7.6 & 25.7 & Jun \\
\hline Reexports & 18.5 & -2.4 & 10.9 & 16.1 & 16.3 & 11.6 & 5.3 & Jun \\
\hline Total Import volume (percent change) & 18.2 & -2.0 & 7.8 & 12.8 & 14.1 & 8.5 & 6.7 & Jun \\
\hline Current account (in billions of US\$) & 7.0 & 9.8 & 12.4 & 16.5 & 15.7 & 20.3 & 1.9 & Jun \\
\hline Net equity inflow (in billions of US\$) & 29.4 & -23.5 & -14.4 & -4.2 & -28.5 & -14.6 & -9.3 & Jun \\
\hline Gross official reserves (in billions of US\$) & 107.6 & 111.2 & 111.9 & 118.4 & 123.6 & 124.3 & 130.3 & Sep \\
\hline In months of retained imports & 18.0 & 20.4 & 22.6 & 23.3 & 21.2 & 19.8 & 18.4 & Jun \\
\hline In percent of monetary base & 388.7 & 377.0 & 354.0 & 314.6 & 325.7 & 340.1 & 347.5 & Sep \\
\hline In percent of broad money $1 /$ & 23.0 & 24.4 & 24.8 & 24.2 & 23.1 & 22.1 & 20.9 & Sep \\
\hline In percent of Hong Kong dollar M3 & 41.9 & 43.0 & 43.5 & 43.4 & 43.4 & 41.2 & 38.0 & Sep \\
\hline Short-term debt (in billions of US\$) 2/ & $\ldots$ & $\ldots$ & 223.8 & 250.5 & 308.5 & 301.7 & 318.5 & Jun \\
\hline In percent of gross reserves & $\ldots$ & $\ldots$ & 200.0 & 211.6 & 249.6 & 242.8 & 251.5 & Jun \\
\hline 1-yr forward exchange rate premium (in pips, annual average) & -35.5 & 52.7 & 138.8 & 34.0 & -704.8 & -448.9 & -518.5 & Jan-Sep \\
\hline Real exchange rate (percent change) & -3.3 & 0.3 & -4.8 & -9.0 & -6.6 & -2.1 & 0.4 & Aug \\
\hline \multicolumn{9}{|l|}{ Financial Sector } \\
\hline HIBOR(3M)-LIBOR (3M) (in basis points, pa) & -41.8 & -17.5 & -0.7 & -26.9 & -126.1 & -49.4 & -88.9 & Sep \\
\hline Hang Seng Index (percent change, end-year) & -11.0 & -24.5 & -18.2 & 34.9 & 13.2 & 4.5 & 27.4 & Oct \\
\hline Residential property prices (percent change, end-year) & -14.5 & -9.8 & -13.0 & 1.9 & 27.4 & 8.2 & 1.8 & Aug \\
\hline \multicolumn{9}{|l|}{ Banking Sector $3 /$} \\
\hline Deposit-loans ratio & 143.3 & 155.9 & 159.8 & 175.3 & 179.3 & 176.0 & 182.2 & Sep \\
\hline Domestic credit growth 4/ & 2.3 & -3.8 & -2.6 & -2.0 & 4.9 & 7.7 & 6.5 & Sep \\
\hline Real credit growth 5/ & 6.3 & -2.3 & 0.4 & 0.6 & 5.3 & 6.7 & 4.3 & Sep \\
\hline Capital adequacy ratio $4 /$ & 17.8 & 16.5 & 15.7 & 15.3 & 15.4 & 14.9 & 15.2 & Jun \\
\hline Nonperforming loans (in percent of total loans) $6,7 /$ & 7.3 & 6.5 & 5.0 & 3.9 & 2.3 & 1.4 & 1.3 & Jun \\
\hline Net interest margin (in percent of interest-bearing assets) $7 /$ & 2.1 & 2.0 & 2.1 & 1.9 & 1.7 & 1.7 & 1.7 & Jun \\
\hline Return on assets (post-tax) $7 /$ & 1.2 & 1.0 & 1.2 & 1.2 & 1.4 & 1.4 & 1.3 & Jun \\
\hline Net open spot position (in billions of US\$) & 25.7 & 24.7 & 18.2 & 15.9 & 28.2 & 30.6 & 31.2 & Jul \\
\hline Net open forward position (in billions of US\$) & -18.7 & -14.6 & -6.7 & -6.4 & -24.5 & -25.8 & -25.9 & Jul \\
\hline Exposure to the Mainland (in percent of total assets) & 2.9 & 2.4 & 2.2 & 2.0 & 2.3 & 2.6 & 2.5 & Jun \\
\hline $\begin{array}{l}\text { Exposure to property sector (in percent of domestic credit) 8/ } \\
\text { Contagion Indicator }\end{array}$ & 49.2 & 50.7 & 51.8 & 50.9 & 50.4 & 50.6 & 49.5 & Sep \\
\hline HK\$-Renminbi forward exchange rate correlation (daily) & -0.1 & 0.1 & -0.1 & 0.9 & 0.8 & 0.7 & -0.4 & Oct \\
\hline Hang Seng-NASDAQ correlation (daily) & 0.7 & 0.9 & 0.8 & 0.9 & 0.6 & 0.8 & 0.1 & Oct \\
\hline
\end{tabular}

Sources: Hong Kong SAR authorities, BIS, and staff estimates.

1/ Broad Money refers to M2.

2/ Official statistics on Hong Kong SAR's external debt are available from the first quarter of 2002.

3/ For all authorized institutions, unless otherwise specified.

4/ For all locally incorporated authorized institutions.

5/ Deflated using CPI.

6/ Refers to total gross classified: "substandard", "doubtful" and "loss".

7/ For retail banks, which comprise all the locally incorporated banks plus a number of the larger foreign banks whose operations are similar to those of the locally incorporated banks, in that they operate a branch network and are active in retail banking.

8/ Exposure to property sector includes loans to finance property investment and development and residential mortage loans. 
Table 3. Hong Kong SAR: Medium-term Balance of Payments, 2003-2011

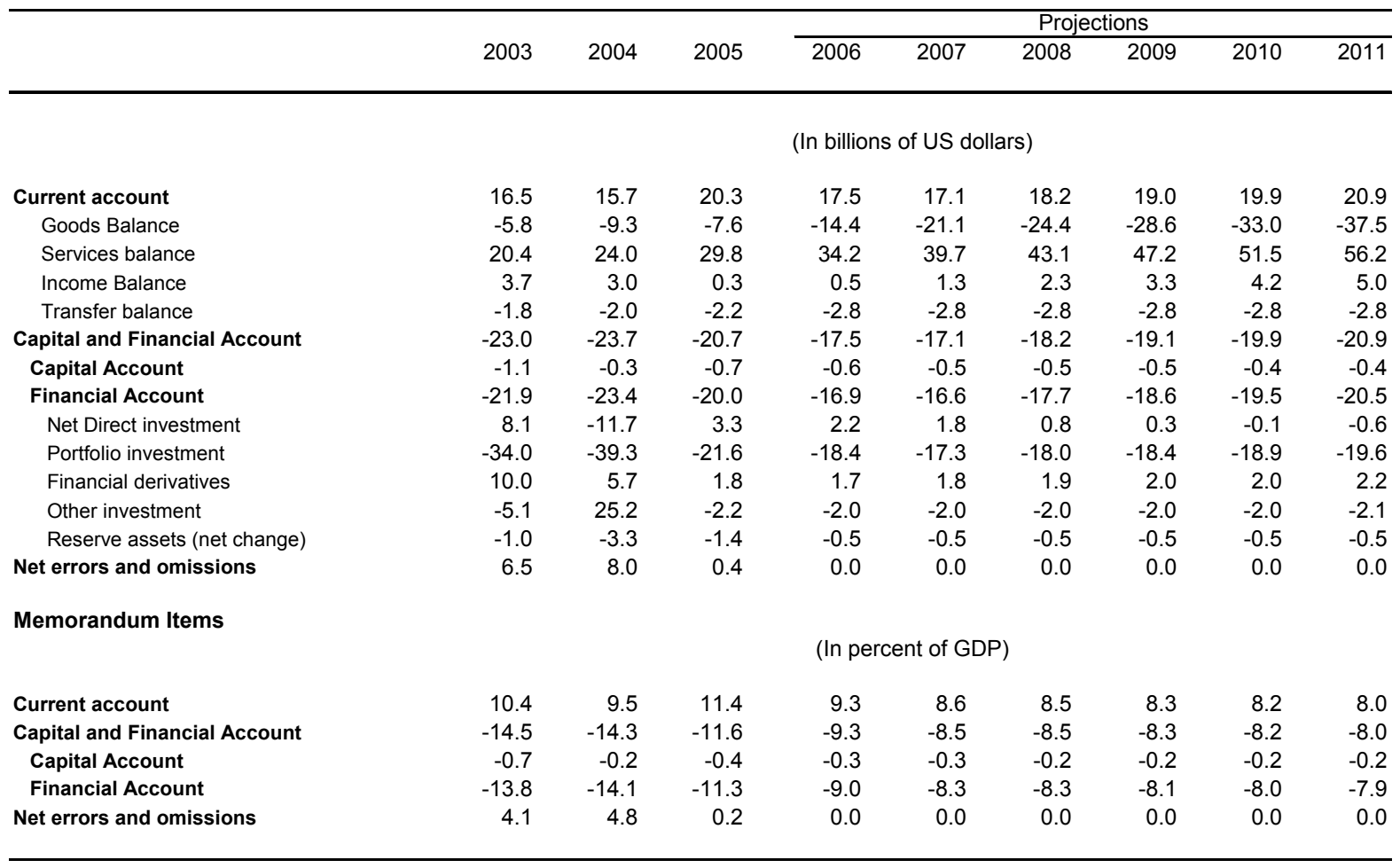

Sources: Hong Kong SAR authorities and staff estimates. 
Table 4. Hong Kong SAR: Consolidated Government Account, FY 03/04-FY2010/11 1/ (In percent of GDP, unless otherwise stated)

\begin{tabular}{|c|c|c|c|c|c|c|c|c|c|}
\hline & \multirow{2}{*}{$\frac{\mathrm{FY} 03 / 04}{\text { Actual }}$} & \multirow{2}{*}{$\frac{\text { FY04/05 }}{\text { Actual }}$} & \multicolumn{2}{|c|}{ FY05/06 } & \multirow[t]{2}{*}{ FY06/07 } & \multirow[t]{2}{*}{ FY07/08 } & \multirow{2}{*}{$\frac{\text { FY08/09 }}{\text { Bud }}$} & \multirow{2}{*}{$\frac{\text { FY09/10 }}{\text { get }}$} & \multirow[t]{2}{*}{ FY10/11 } \\
\hline & & & Budget & Actual & & & & & \\
\hline Revenue & 16.8 & 18.4 & 17.6 & 17.9 & 17.7 & 17.5 & 17.7 & 16.9 & 16.8 \\
\hline Tax & 10.7 & 12.1 & 11.6 & 12.7 & 11.9 & $\ldots$ & $\ldots$ & $\ldots$ & $\ldots$ \\
\hline $\begin{array}{c}\text { Direct Tax } \\
\text { of which }\end{array}$ & 6.5 & 7.5 & 7.2 & 8.1 & 7.7 & $\ldots$ & $\ldots$ & $\ldots$ & $\ldots$ \\
\hline Salaries & 2.3 & 2.6 & 2.5 & 2.7 & 2.6 & $\ldots$ & $\ldots$ & $\ldots$ & $\ldots$ \\
\hline Profits Tax & 4.0 & 4.5 & 4.4 & 5.1 & 4.9 & $\ldots$ & $\ldots$ & $\ldots$ & $\ldots$ \\
\hline Indirect Tax 2/ & 4.2 & 4.6 & 4.4 & 4.6 & 4.2 & $\ldots$ & $\ldots$ & $\ldots$ & $\ldots$ \\
\hline $\begin{array}{l}\text { Non Tax } \\
\text { of which }\end{array}$ & 6.1 & 6.3 & 6.0 & 5.2 & 5.8 & $\ldots$ & $\ldots$ & $\cdots$ & $\ldots$ \\
\hline Land Premium & 0.4 & 2.5 & 2.3 & 2.1 & 2.1 & $\ldots$ & $\ldots$ & $\ldots$ & $\ldots$ \\
\hline Investment Income & 2.1 & 1.1 & 1.0 & 0.8 & 1.3 & 1.0 & 1.0 & 1.0 & 1.0 \\
\hline Expenditure & 20.1 & 18.8 & 18.3 & 16.9 & 17.2 & 16.8 & 16.2 & 15.6 & 15.1 \\
\hline Current & 16.0 & 14.9 & 14.4 & 13.5 & 13.8 & $\ldots$ & $\ldots$ & $\ldots$ & $\ldots$ \\
\hline Capital 3/ & 4.1 & 3.9 & 3.9 & 3.3 & 3.4 & $\ldots$ & $\ldots$ & $\ldots$ & $\ldots$ \\
\hline Overall Balance & -3.3 & -0.3 & -0.8 & 1.0 & 0.6 & 0.7 & 1.6 & 1.3 & 1.8 \\
\hline \multicolumn{10}{|l|}{ Memorandum Items: } \\
\hline Operating Balance & -2.3 & -0.8 & 0.9 & -0.2 & 0.0 & 0.1 & 0.5 & 0.8 & 1.2 \\
\hline Primary Balance 4/ & -5.4 & -1.4 & -1.8 & 0.3 & -0.7 & -0.3 & 0.6 & 0.3 & 0.8 \\
\hline Structural Balance 5/ & -4.8 & -2.7 & -2.1 & -0.6 & 0.4 & 0.4 & 0.6 & 0.9 & 1.3 \\
\hline Fiscal Reserves & 22.3 & 22.9 & 20.0 & 22.5 & 21.8 & 21.2 & 21.4 & 21.3 & 21.9 \\
\hline (Months of spending) & 13.4 & 14.7 & 13.1 & 16.0 & 15.2 & 15.2 & 15.9 & 16.4 & 17.4 \\
\hline
\end{tabular}

Sources: Hong Kong SAR Government, and staff estimates.

1/ Fiscal year begins on April 1. FY2006-10 projections are based on authorities' medium-term fiscal framework.

2/ Indirect tax includes general rates, bets and sweeps tax, stamp duties, fees and charges (tax-loaded fees), hotel accommodation tax,

air passenger departure tax, motor vehicle taxes, royalties and estate duty.

$3 /$ Includes non-recurrent operating expenditure.

4/ Overall balance excluding investment income.

5/ Staff estimate used to measure the impact of fiscal policy on domestic demand. It excludes asset transactions and cyclical fluctuations. 


\section{Statement by the IMF Staff Representative}

December 14, 2006

This statement reports on macroeconomic data and new information on the government's tax reform proposal released since the Staff Report was finalized. These new developments do not change the thrust of the staff appraisal.

\section{The Hong Kong SAR economy grew by 6.8 percent (year-on-year) in the third quarter} of 2006. This was faster than anticipated in the staff report, due to stronger Mainland-related exports of goods and financial services, and continued strong domestic demand. Headline inflation moderated in October, in line with international oil prices, to around 2 percent. Reflecting these developments, staff expects growth to be reach around $6 \frac{1}{2}$ percent in 2006 , up from the $5 \frac{3}{4}$ percent projected in the staff report, and $5 \frac{1}{2}$ percent in 2007 . Inflation is likely to be slightly lower at around 2 percent for 2006 (the staff report projected the rate at 2.3 percent).

\section{On December 5, the government released an interim report on their tax reform public} consultation. The report concluded that the majority of the public agreed that the current tax base was narrow and needed to be broadened. The government was urged to explore alternatives to broaden the tax base, including options other than a GST, for which there was only limited support. The government will, thus, continue to seek views on such options during the remainder of the consultation, which ends in March 2007. 


\section{INTERNATIONAL MONETARY FUND}

\section{Public Information Notice}

EXTERNAL RELATIONS DEPARTMENT
Public Information Notice (PIN) No. 07/02

FOR IMMEDIATE RELEASE

January 8, 2007
International Monetary Fund

$70019^{\text {th }}$ Street, NW

Washington, D. C. 20431 USA

\section{IMF Executive Board Concludes 2006 Article IV Consultation Discussions with the People's Republic of China-Hong Kong Special Administrative Region}

On December 15, 2006, the Executive Board of the International Monetary Fund (IMF) concluded the Article IV consultation discussions with the People's Republic of China-Hong Kong Special Administrative Region. ${ }^{1}$

\section{Background}

Hong Kong SAR has recovered strongly from a series of shocks in recent years and, as expected, the pace of growth is now moderating. Growth was 6.8 percent (year-on-year) in the first three quarters of 2006, somewhat slower than the 7.3 percent recorded in 2005. The continued brisk pace of growth, and its pick-up in the third quarter relative to the second quarter, was due to stronger Mainland-related exports of goods and financial services, and continued strong domestic demand. Household and corporate balance sheets remain robust. Significantly, job creation has continued to improve across all sectors and skill levels, bringing the unemployment rate to its lowest level in more than five years, and inflation is modest.

On the policy front, this fiscal year's budget continues to take advantage of the strong economy to strengthen the fiscal position. Last fiscal year, revenue growth and expenditure restraint helped achieve the first budget surplus (of around 1 percent of GDP) since the Asian crisis.

\footnotetext{
${ }^{1}$ Under Article IV of the IMF's Articles of Agreement, the IMF holds bilateral discussions with members, usually every year. A staff team visits the country, collects economic and financial information, and discusses with officials the country's economic developments and policies. On return to headquarters, the staff prepares a report, which forms the basis for discussion by the Executive Board. At the conclusion of the discussion, the Managing Director, as Chairman of the Board, summarizes the views of Executive Directors, and this summary is transmitted to the country's authorities.
} 
On current economic and spending trends, this year's target surplus of $1 / 2$ percent of GDP is likely to be modestly over performed. In addition, the refinements made by the authorities to the Linked Exchange Rate System in May 2005 have dampened renminbi-related speculative pressures by effectively limiting currency movements against the U.S. dollar to a narrow band.

Looking ahead, staff expects growth to moderate to around $5 \frac{1}{2}$ percent in 2007 . Inflation is expected to firm modestly with the tightening labor market and as rents adjust to previous increases in property prices. Although the external position should remain strong, the current account surplus is expected to narrow with maturing external demand. The main near-term risks to this outlook are a sharper slowdown in global demand (particularly in the United States) and a rise in protectionist sentiments against China.

Over the medium term, much will depend on how well the evolving financial integration with the Mainland is managed and leveraged, and competitive pressures from other regional financial centers withstood. Although fundraising by Chinese entities reached new heights in 2006, the extent of financial integration with the Mainland is still small relative to its potential. Increasing Hong Kong SAR's role in the direct intermediation of the Mainland's domestic savings will be key for the continued success of its financial center. Consequently, continued cooperation and coordination with the Mainland's financial authorities, which have advanced well, remain crucial.

\section{Executive Board Assessment}

Executive Directors welcomed the Hong Kong SAR economy's sustained expansion, now in its fourteenth consecutive quarter, which they attributed to the authorities' skillful macroeconomic management, the flexibility of Hong Kong SAR's markets, and the economy's highly developed financial infrastructure. Looking ahead, Directors noted that, while growth is likely to moderate, it will remain strong over the medium term if financial integration with the Mainland is further deepened and managed well.

Directors commended the authorities on making use of the current strong economy to strengthen the fiscal position and address the longer-term fiscal challenges of revenue volatility and age-related spending pressures. They welcomed the growing public recognition of the need to broaden the tax base, and public discussion of ways to do it. In this context, several Directors noted that a low-rated and broad-based goods and services tax would be an efficient way to broaden the tax base, if targeted compensation is provided to alleviate the resulting burden on low-income households. Directors also suggested that the authorities consider seeking other ways to stabilize investment income through arrangements with the Exchange Fund.

Directors reiterated their support for the authorities' commitment to the Linked Exchange Rate System, and noted that the refinements undertaken in May 2005 appear to have fortified the system against short-term shocks. Adjustment to longer-lasting shocks would, however, continue to rely on the demonstrated flexibility of Hong Kong SAR's domestic markets and its strong institutions. At the same time, Directors noted that some non-price competitiveness issues warrant close attention, and therefore welcomed the envisaged competition policy law that would add to the economy's traditional strengths. Directors cautioned, however, that the 
design of labor market regulation needs to ensure that the balance between market flexibility and adequate worker protection is maintained.

Directors noted that financial integration with the Mainland would be a key driver of future economic prospects. They encouraged continued coordination between the authorities and their Mainland counterparts on ways to use Hong Kong SAR's advanced financial platform to improve financial intermediation in the Mainland, noting that such coordination would be of benefit to both economies.

Directors concurred with the authorities that enhancing financial sector supervision is critical to safeguarding the competitiveness of the financial center. In this regard, they welcomed progress on cross-border regulatory supervision, preparations for Basel II adoption, and plans to broaden Anti-Money Laundering and Combating the Financing of Terrorism (AML/CFT) enforcement.

Public Information Notices (PINs) form part of the IMF's efforts to promote transparency of the IMF's views and analysis of economic developments and policies. With the consent of the country (or countries) concerned, PINs are issued after Executive Board discussions of Article IV consultations with member countries, of its surveillance of developments at the regional level, of post-program monitoring, and of ex post assessments of member countries with longer-term program engagements. PINs are also issued after Executive Board discussions of general policy matters, unless otherwise decided by the Executive Board in a particular case. The Staff Report for the 2006 Article IV Consultation with the People's Republic of China-Hong Kong Special Administrative Region is also available. 
People's Republic of China, Hong Kong Special Administrative Region: Selected Economic and Financial Indicators 1/

\begin{tabular}{|c|c|c|c|c|c|}
\hline & 2003 & 2004 & 2005 & 2006 & 2007 \\
\hline & & & & \multicolumn{2}{|c|}{ Proj. } \\
\hline Real GDP (percent change) & 3.2 & 8.6 & 7.3 & 6.8 & 5.4 \\
\hline Real domestic demand (contribution) & 0.1 & 4.7 & 1.7 & 4.4 & 5.0 \\
\hline Foreign balance (contribution) & 3.1 & 3.9 & 5.6 & 2.5 & 0.4 \\
\hline \multicolumn{6}{|l|}{ Inflation (percent change) } \\
\hline Consumer prices & -2.6 & -0.4 & 1.0 & 2.0 & 2.2 \\
\hline GDP deflator & -6.3 & -3.6 & -0.2 & -0.1 & 0.9 \\
\hline Employment (percent change) & -0.4 & 2.8 & 2.3 & 2.9 & 2.2 \\
\hline Unemployment rate (percent, period average) & 7.9 & 6.8 & 5.6 & 4.8 & 4.4 \\
\hline Real wages & 0.2 & -1.2 & -0.4 & $\ldots$ & $\ldots$ \\
\hline \multicolumn{6}{|l|}{ Government budget (percent of GDP) 2/ } \\
\hline Revenue & 16.8 & 18.4 & 17.9 & 17.7 & 17.5 \\
\hline Expenditure & 20.1 & 18.8 & 16.9 & 17.2 & 16.8 \\
\hline Consolidated budget balance & -3.3 & -0.3 & 1.0 & 0.6 & 0.7 \\
\hline \multicolumn{6}{|l|}{ External balances (in billions of US\$) } \\
\hline Merchandise trade balance & -5.8 & -9.3 & -7.6 & -10.1 & -15.8 \\
\hline (In percent of GDP) & -3.6 & -5.6 & -4.3 & -5.3 & -7.8 \\
\hline Current account & 16.5 & 15.7 & 20.3 & 20.7 & 20.4 \\
\hline (In percent of GDP) & 10.4 & 9.5 & 11.4 & 10.9 & 10.1 \\
\hline \multicolumn{6}{|l|}{ Foreign exchange reserves $3 /$} \\
\hline (In billions of US\$, end of period) & 118.4 & 123.6 & 124.3 & 128.2 & 128.7 \\
\hline (In percent of GDP) & 74.7 & 74.5 & 69.9 & 67.6 & 63.8 \\
\hline
\end{tabular}

Sources: Data provided by the Hong Kong SAR authorities; and IMF staff estimates and projections. 1/ Data as at December 15, 2006.

2/ Authorities' FY2006/07 Budget estimates.

3/ Includes Land Fund assets from 1997 (US\$17.5 billion at end-1997). 